\title{
Advances in airborne microorganisms detection using biosensors: A critical review
}

\author{
Jinbiao Ma ${ }^{1,2 \#}$, Manman Du ${ }^{1,2 \#}$, Can Wang $(\varangle)^{1,2}$, Xinwu Xie $(\bowtie)^{3,4}$, Hao Wang ${ }^{3,5}$, Qian Zhang ${ }^{6}$ \\ 1 School of Environmental Science and Engineering, Tianjin University, Tianjin 300072, China \\ 2 Tianjin Key Laboratory of Indoor Air Environmental Quality Control, Tianjin 300072, China \\ 3 Institute of Medical Support Technology, Academy of Military Science, Tianjin 300161, China \\ 4 National Bio-Protection Engineering Center, Tianjin 300161, China \\ 5 School of Electronic Information and Automation, Tianjin University of Science and Technology, Tianjin 300222, China \\ 6 School of Mechanical Engineering and Safety Engineering, Institute of Particle Technology, University of Wuppertal, \\ Wuppertal D-42119, Germany
}

\section{H I G H L I G H T S}

- Airborne microorganism detection methods are summarized.

- Biosensors play an important role in detecting airborne microorganisms.

- The principle of biosensor detection of airborne microorganisms is introduced.

- The application and progress of biosensor in recent years is summarized.

- The future perspectives of biosensor are identified.

\section{A R T I C L E I N F O}

\section{Article history:}

Received 28 October 2020

Revised 8 February 2021

Accepted 22 February 2021

Available online 5 April 2021

\section{Keywords:}

Biosensor

Airborne microorganisms

Microbiological detection technology

\section{GRAPHIC A B T RACT}

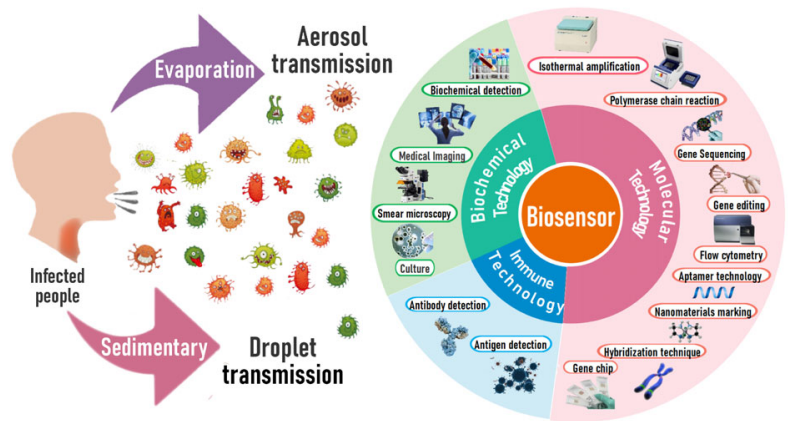

\section{A B S T R A C T}

Humanity has been facing the threat of a variety of infectious diseases. Airborne microorganisms can cause airborne infectious diseases, which spread rapidly and extensively, causing huge losses to human society on a global scale. In recent years, the detection technology for airborne microorganisms has developed rapidly; it can be roughly divided into biochemical, immune, and molecular technologies. However, these technologies still have some shortcomings; they are time-consuming and have low sensitivity and poor stability. Most of them need to be used in the ideal environment of a laboratory, which limits their applications. A biosensor is a device that converts biological signals into detectable signals. As an interdisciplinary field, biosensors have successfully introduced a variety of technologies for bio-detection. Given their fast analysis speed, high sensitivity, good portability, strong specificity, and low cost, biosensors have been widely used in environmental monitoring, medical research, food and agricultural safety, military medicine and other fields. In recent years, the performance of biosensors has greatly improved, becoming a promising technology for airborne microorganism detection. This review introduces the detection principle of biosensors from the three aspects of component identification, energy conversion principle, and signal amplification. It also summarizes its research and application in airborne microorganism detection. The new progress and future development trend of the biosensor detection of airborne microorganisms are analyzed.

(C) Higher Education Press 2021

\section{Introduction}

$\triangle$ Corresponding authors

E-mail: wangcan@tju.edu.cn (C. Wang); xinwuxie@163.com (X. Xie)

${ }^{\#}$ These authors contributed equally to this work.

Special Issue-Bioaerosol, Environment and Health (Responsible Editors: Can Wang, Jungho Hwang, Jingkun Jiang \& Maosheng Yao)
1.1 Hazards of airborne infectious diseases and airborne microorganisms

The corona virus disease 2019 (COVID-19) is considered the largest global pandemic since the 20th century, and it 
has not yet been effectively controlled globally. Indeed, frequent outbreaks of major airborne infectious diseases have been recently reported, which have had a significant impact on human life and health and on the global economy and society. According to the official report of the World Health Organization, the major infectious diseases in recent years are summarized, as shown in Table 1. Every infectious disease is caused by specific microorganisms, including viruses, bacteria, fungi and parasites. Among them, microorganisms that spread through air are called airborne microorganisms (Després et al., 2012). Airborne microorganisms can be transmitted through human exhalation (Doremalen et al., 2020) and show strong survivability in air. Airborne infectious diseases can be spread from person to person through airborne microorganisms (Hoehl et al., 2020; Yu et al., 2020; Jiang et al., 2021). They spread rapidly and extensively (Setti et al., 2020), which can easily cause social panic. (Zheng et al., 2018; Wang et al., 2019a).

1.2 Necessity and challenge of airborne microorganism detection

Timely identification, monitoring, and investigation of airborne microorganism transmission in the human environment is particularly important to prevent the outbreak of airborne diseases in the population. At present, however, most of the test samples of airborne microorganisms come from clinical samples, which mainly include upper respiratory tract (nasopharyngeal swab and deep throat saliva), lower respiratory tract (alveolar lavage fluid and sputum), and body fluids (Cui and Zhou, 2020). The collection of different types of samples can affect microorganism detection. Clinical samples often have high detection efficiency and accuracy, but they require professional operation and bring discomfort to the test subjects. Most technologies require on-site sampling and further tests in the laboratory, with complex operation process and long detection time (Wang et al., 2019a).
Correspondingly, the direct detection of air samples has received widespread attention in recent years, and air samples mainly include exhaled breath and aerosols (Razzini et al., 2020). On-site air sample detection features a short detection time, flexibility, and convenience. However, it is easily affected by environmental factors such as wind speed, temperature, light intensity, and air humidity. In addition, the content of airborne microorganisms in the environment is low, with a wide variety of species and large number of impurities, which makes onsite detection difficult.

\subsection{Airborne microorganism detection methods}

The detection methods for airborne microorganisms can be roughly summarized as biochemical, immune, and molecular technologies. After years of development, some detection methods have become mature and new technologies are emerging constantly. However, most of the existing technologies have outstanding performance in aspects of detection time, specificity, and sensitivity, while some limitations exist in other aspects, which are difficult to meet the requirements of airborne microorganism detection. Several common detection methods are compared in Table 2.

In recent years, in view of the advantages and disadvantages of different detection technologies, diversified technology combinations have emerged, greatly improving the detection capabilities of airborne microorganisms (Zheng et al., 2018). As an interdisciplinary field, biosensors have been extensively studied in recent years, Figure 1 summarizes technologies that have been successfully applied to biosensors or have the potential to be combined with biosensors. They have been widely used because of their short detection time, fast analysis speed, and flexible portability. As a routine laboratory microbial detection technology, biochemical technology is used in combination with biosensors for the preliminary treatment of samples (Peláez et al., 2020). On the basis of the specific

Table 1 Major incidents of airborne infectious diseases in recent years

\begin{tabular}{|c|c|c|c|c|}
\hline $\begin{array}{l}\text { Airborne } \\
\text { diseases }\end{array}$ & $\begin{array}{c}\text { Airborne } \\
\text { microorganisms }\end{array}$ & Parasitifer & Duration & Impact \\
\hline$\overline{\text { SARS }}$ & SARS-CoV & Bat & $2002.11-2003.07$ & $\begin{array}{l}8069 \text { confirmed cases and } 774 \text { deaths } \\
\text { (as at July 2003) }\end{array}$ \\
\hline H1N1 Flu & Influenza virus $A$ & Birds and mammals & 2009.04-2010.08 & $\begin{array}{l}68474274 \text { confirmed cases and } 18449 \text { deaths } \\
\text { (as at August 2009) }\end{array}$ \\
\hline MERS & MERS-CoV & Camel & 2012.09-2018.09 & $\begin{array}{l}2562 \text { confirmed cases and } 881 \text { deaths } \\
\text { (as at September 2020) }\end{array}$ \\
\hline H7N9 avian influenza & AIV & Poultry & 2013.03-2017.09 & $\begin{array}{l}1564 \text { confirmed cases and } 609 \text { deaths } \\
\text { (as at October 2017) }\end{array}$ \\
\hline COVID-19 & SARS-CoV-2 & $\mathrm{Bat}^{*}$ & $2019.12-$ & $\begin{array}{l}\text { More than } 107 \text { million confirmed cases and } 2.3 \\
\text { million deaths (as at February 2021) }\end{array}$ \\
\hline
\end{tabular}

Note: *the potential parasitifer. 
Table 2 Comparison of detection methods for airborne microorganisms

\begin{tabular}{|c|c|c|c|}
\hline$\overline{\text { Detection method }}$ & Advantage & Disadvantage & Reference \\
\hline Culture & $\begin{array}{l}\text { 1. Relatively simple operation } \\
\text { 2. Low cost, and less equipment investment } \\
\text { 3. Used for strain typing and drug resistance } \\
\text { detection }\end{array}$ & $\begin{array}{l}\text { 1. Large workload, and long detection time } \\
\text { 2. Low sensitivity } \\
\text { 3. Difficult to cultivate some microorganisms or } \\
\text { require high biological safety }\end{array}$ & $\begin{array}{l}\text { Hudu et al., 2016; Gupta } \\
\text { and Kakkar, } 2018\end{array}$ \\
\hline Medical imaging & $\begin{array}{l}\text { 1. Short detection time } \\
\text { 2. fast analysis speed }\end{array}$ & $\begin{array}{l}\text { 1. Need professional equipment } \\
\text { 2. Low specificity } \\
\text { 3. Invasive } \\
\text { 4. Not suitable for early-stage patients }\end{array}$ & $\begin{array}{l}\text { Brenner and Hall, 2007; } \\
\text { Seibel et al., } 2020\end{array}$ \\
\hline Immune technology & $\begin{array}{l}\text { 1. Medium sensitivity, capable of determining } \\
\text { small or limited amounts of enzymes in samples } \\
\text { 2. Medium specificity, not easily affected by } \\
\text { impurities } \\
\text { 3. Medium detection time, suitable for large number } \\
\text { of samples }\end{array}$ & $\begin{array}{l}\text { 1. Prone to "false positives" affecting the results } \\
\text { 2. Many measurement steps and complicated operation } \\
\text { 3. High measurement cost }\end{array}$ & $\begin{array}{l}\text { Phunpae et al., 2014; } \\
\text { Fronczek and Yoon, } \\
\text { 2015; Mekonnen et al., } \\
2020\end{array}$ \\
\hline $\begin{array}{l}\text { Polymerase chain } \\
\text { reaction }\end{array}$ & $\begin{array}{l}\text { 1. High sensitivity } \\
\text { 2. High specificity, low sample purity requirements } \\
\text { 3. Used for strain typing and drug resistance } \\
\text { detection } \\
\text { 4. Medium detection time }\end{array}$ & $\begin{array}{l}\text { 1. High measurement cost } \\
\text { 2. Complex cyclic process, high technical requirements, } \\
\text { and professional equipment } \\
\text { 3. Unable to distinguish between living and dead } \\
\text { microorganisms }\end{array}$ & $\begin{array}{l}\text { Weile and knabbe, 2009; } \\
\text { Paolucci et al., 2010; } \\
\text { Eddabra and Ait Ben- } \\
\text { hassou, } 2018\end{array}$ \\
\hline Gene Sequencing & $\begin{array}{l}\text { 1. Good stability, and specificity } \\
\text { 2. High detection accuracy }\end{array}$ & $\begin{array}{l}\text { 1. Large workload, and long detection time } \\
\text { 2. High measurement cost }\end{array}$ & Schlaberg et al., 2017 \\
\hline Biosensor & $\begin{array}{l}\text { 1. High sensitivity, and high specificity } \\
\text { 2. Short detection time, and fast analysis speed } \\
\text { 3. Flexible and portable, suitable for on-site testing } \\
\text { 4. Low cost }\end{array}$ & $\begin{array}{l}\text { 1. High sample purity requirements, weak } \\
\text { anti-interference ability } \\
\text { 2. Poor detection stability } \\
\text { 3. Poor repeatability }\end{array}$ & $\begin{array}{l}\text { Nidzworski et al., 2014; } \\
\text { Cui and Zhou, } 2020\end{array}$ \\
\hline
\end{tabular}

Note: High sensitivity means that the lowest detection concentration is roughly less than $10 \mathrm{CFU} / \mathrm{mL}$, medium sensitivity means that the lowest detection concentration is roughly between 10 and $1000 \mathrm{CFU} / \mathrm{mL}$, and low sensitivity means that the lowest detection concentration is roughly higher than $1000 \mathrm{CFU} / \mathrm{mL}$; High specificity means single base mismatches can be detected, medium specificity means that specific identification substances of microorganisms can be detected, low specificity means that different types of microorganisms can not be detected well.

combination of antibody and antigen, immune technology introduces biosensors to construct an immunosensor, which has been extensively used in the detection of airborne microorganisms (Shen et al., 2009; Mavrikou et al., 2020). Good results have been obtained for detecting SARS-CoV (Park et al., 2009), Influenza virus A (Nidzworski et al., 2014), AIV (Huang et al., 2016), SARS-CoV-2 (Seo et al., 2020), and other airborne microorganisms. Molecular technology, as a new technology, can improve sensors, and it is mainly used for the identification of components and signal amplification of sensors (Xu et al., 2016; Freije et al., 2019). Zhang et al. developed a nanosensor combined with RT-PCR amplification and achieved the rapid detection of dengue virus using a PNA probe binding on it (Zhang et al., 2010). As an interdisciplinary field, biosensors integrate the advantages of many technologies and have bright prospects in the detection of airborne microorganisms.

\section{Biosensor detection principle}

Biosensor is a special device that uses component identification as the biological sensing unit, converting biological signals into detectable signals using an appro- priate energy conversion principle. It also uses appropriate methods to achieve signal amplification with high selectivity to the target object. Its basic composition is shown in Fig. 2.

\subsection{Components identification}

The detection of biosensors is realized by the specificity of component identification. According to the different component identification used, biosensors can be divided into two categories. The first type is the cell-based biosensor (Mavrikou et al., 2020), which has certain requirements on the state and activity of the cell. It monitors and analyzes the changes in metabolites during cell respiration (Xu et al., 2016). The second category is the biosensor based on the detection of microbial metabolites, including sensors based on aptamers (Wu et al., 2019), antibodies (Seo et al., 2020), and nucleic acids (Liu et al., 2018c). This type of biosensor has no special requirements for the survival state of microbial cells and is a commonly used for the component identification of biosensors. Gopinath et al. selected the $16 \mathrm{kDa}$ heat shock protein of Mycobacterium tuberculosis (MTB) for component identification and coupled it to gold nanoparticles 


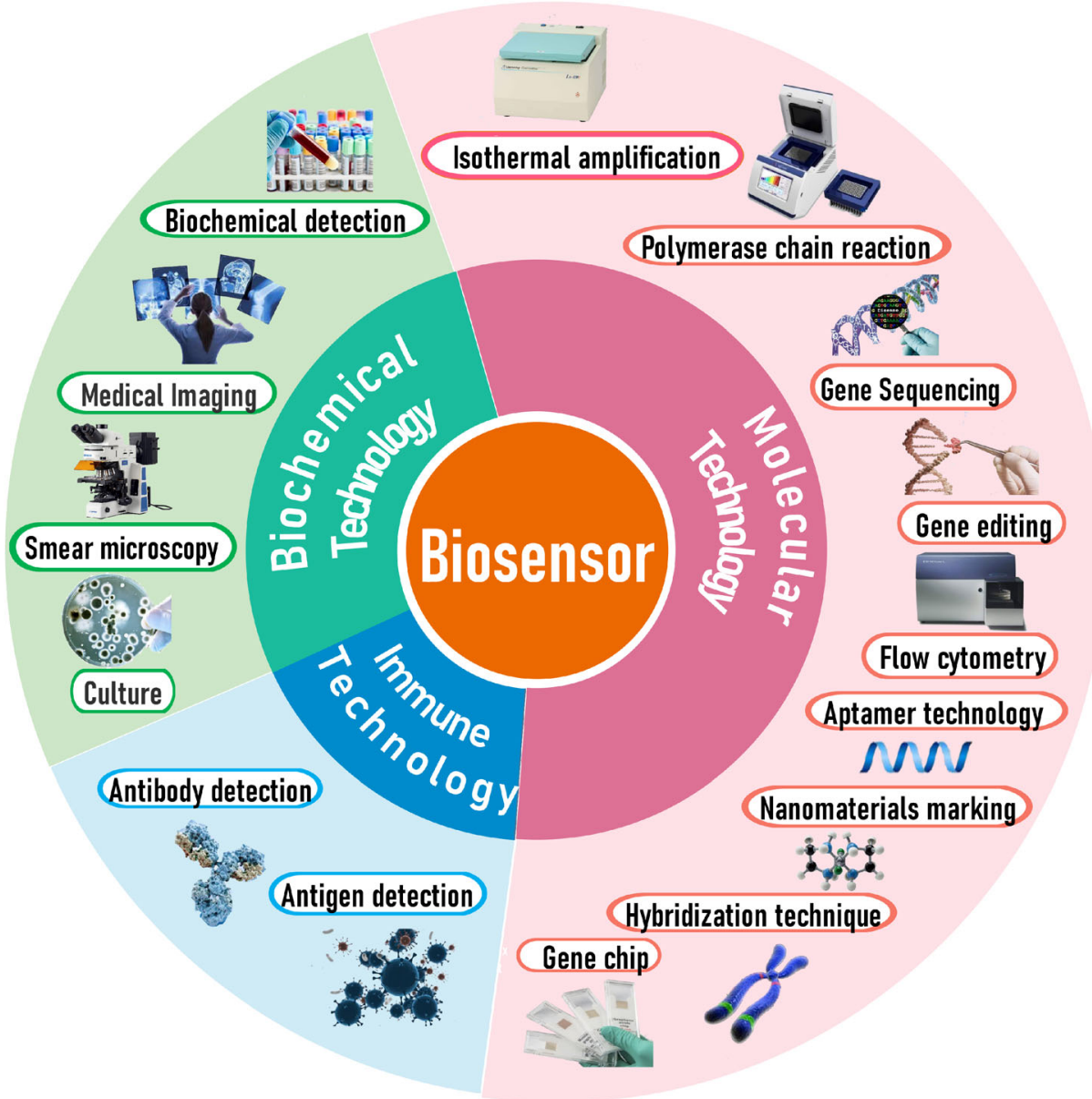

Fig. 1 Airborne microorganism detection methods based on biosensors.

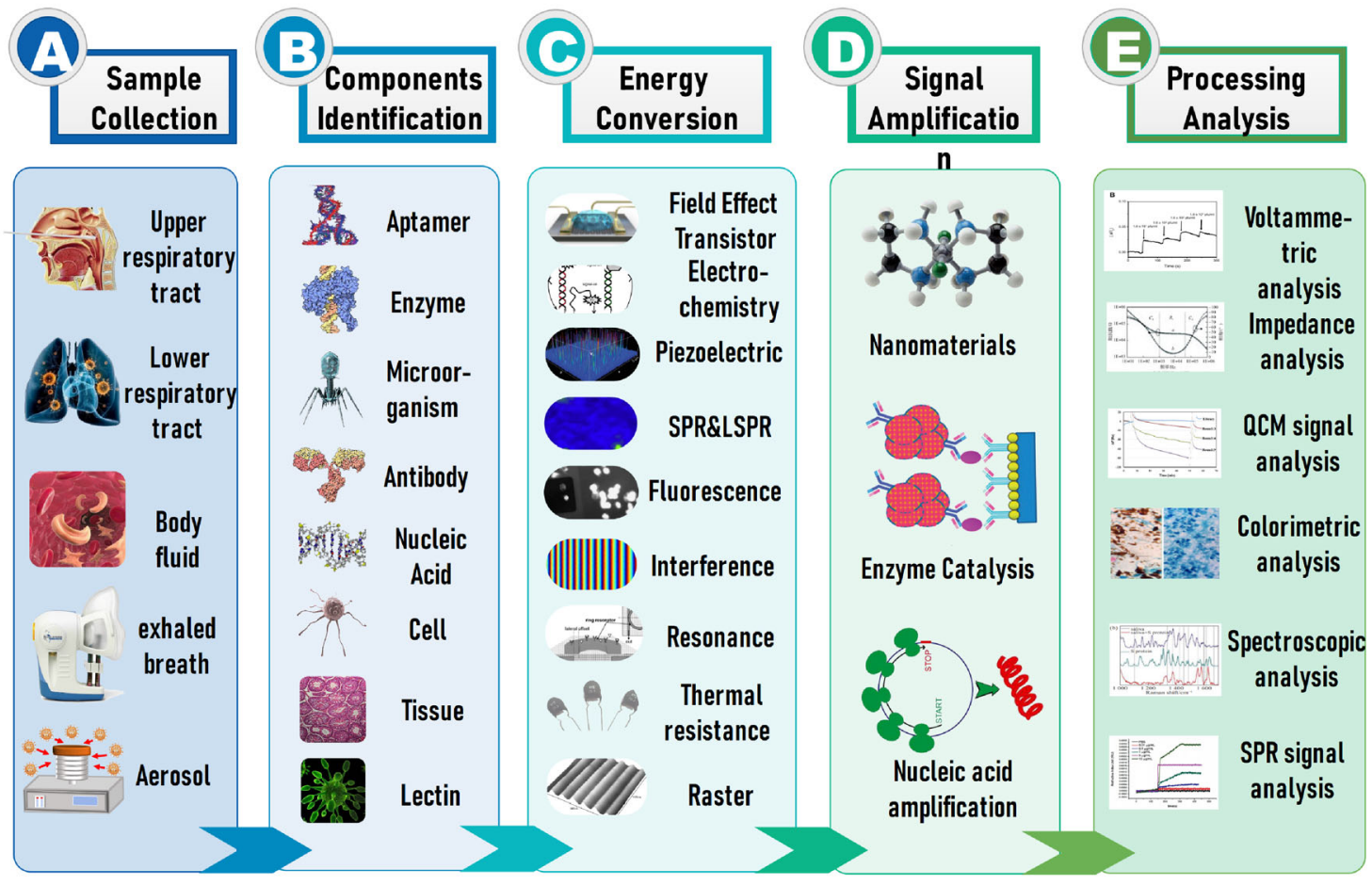

Fig. 2 Principle flow chart of airborne microorganisms detection using biosensors. 
with a detection limit as low as $100 \mathrm{fM}$ (Gopinath et al., 2016).

Aptamers are artificially synthesized short singlestranded DNA or RNA, which can develop high-affinity molecules to specifically recognize the desired target. Aptamers have many advantages compared with antibodies, such as short generation time, low manufacturing cost, high variability, good thermal stability and broad application (Zhang et al., 2019c). Kwon et al. used aptamer biosensors to directly detect avian influenza virus in clinical samples of chicken serum, with a detection limit of 5.9 pM (Kwon et al., 2020).

\subsection{Principle of energy conversion}

The biosensor uses the principle of appropriate energy conversion to convert identifiable biological signals into detectable electrical, optical, acoustic, or thermal signals. In recent years, electrical and optical biosensors have developed rapidly.

\subsubsection{Electrical biosensor}

Electrical biosensors are the most widely used and the earliest developed biosensors in the field (Cesewski and Johnson, 2020). This type of biosensor mainly uses electrical signals for detection, such as electrochemistry, field-effect transistor (FET), and piezoelectric sensors. The electrochemical biosensor uses the electrochemical signal generated by the biorecognition process on the electrode surface for detection. Depending on the signal type, electrochemical biosensors can be divided into three types of sensors: volt-ampere (Seo et al., 2020), impedance (Xu et al., 2016), and ampere (Bhattacharyya et al., 2016). The FET biosensor uses the biological recognition process to cause changes in the electronic characteristics of semiconductor channels for detection. The Piezoelectric sensor uses the biometric process to detect surface charges when piezoelectric materials are pressed. Mavrikou et al. used a new type of electrochemical sensor to detect the S1 spike protein expressed on the surface of the virus SARS-CoV-2. The results are provided within $3 \mathrm{~min}$, and the detection limit is $1 \mathrm{fg} / \mathrm{mL}$ (Mavrikou et al., 2020). Seo et al. constructed a FET biosensor, detected the spike protein of SARS-CoV-2 at a concentration of $1 \mathrm{fg} / \mathrm{mL}$, and successfully detected the culture medium (detection limit $16 \mathrm{PFU} /$ $\mathrm{mL}$ ) and clinical specimens (detection limit $2.42 \times 10^{2}$ copies/mL) of SARS-CoV-2 (Seo et al., 2020). Zhang developed a new type of piezoelectric sensor combined with aptamer technology to detect MTB with a limit of 100 CFU/mL (Zhang et al., 2019b).

The electrical biosensor is an important branch of biosensor, which fixes the bio-recognition element to the electrode surface, and converts the chemical or pressure signal generated by the combination of the target microorganism and the recognition element into a measurable electrical signal. It has been widely studied for its high sensitivity, fast response, high specificity, portability, and low cost (Cesewski and Johnson, 2020).

\subsubsection{Optical biosensor}

The optical biosensor is a biosensor that converts the signal of the detected object into a detectable optical signal. Optical biosensors mainly utilize the properties of light, such as fluorescence (Wu et al., 2019), surface plasma resonance (SPR) (Peláez et al., 2020) and colorimetric (Briceno et al., 2019) sensors. The fluorescence sensor uses the unique photophysical properties of fluorescent nanomaterials for labeling and detection of microorganisms (Zheng et al., 2019). The SPR biosensor uses the interaction of biomolecules to cause the instantaneous light signal change on the surface of the nano-layer metal film and then convert it into an electrical signal for detection. The colorimetric biosensor is based on the change in the number of target microorganisms in the sample, which can cause the color change of the detection solution to detect the target microorganisms (Wang et al., 2020a). Wei et al. developed a fluorescent immunological biosensor that uses fluorescent dyes to modify DNA probes, which can be used to detect H5N1 antibodies in serum samples (Wei et al., 2013). Peláez et al. used the SPR biosensor for the direct and label-free detection of the HspX recombinant antigen of MTB. Moreover, their process involved simple pretreatment of sputum specimens without any additional amplification steps, with a detection limit of $0.63 \mathrm{ng} / \mathrm{mL}$ (Peláez et al., 2020). Briceno et al. used a colorimetric biosensor to complete detection within $20 \mathrm{~min}$ and can reach the sensitivity level of the culture method (Briceno et al., 2019).

The optical biosensor is an emerging research direction of sensing in recent years. Through biological or chemical luminescence sensing, real-time detection of the object can be realized without modifying the label of the target. The optical biosensor belongs to the category of traditional physical sensing, with sensitive response and strong antiinterference ability.

\subsection{Methods of signal amplification}

In the detection of airborne microorganisms, the actual sample content is particularly low, so analysis and detection using conventional biological analysis methods are difficult to achieve. Certain methods are required to achieve signal amplification and improve the sensitivity of the sensor. Common signal amplification strategies include nanomaterial amplification technology (Xiao et al., 2020), enzyme catalysis amplification technology (Xie et al., 2019a), and nucleic acid-based amplification technology (Wu et al., 2019). 


\subsubsection{Nanomaterial amplification technology}

The physical and chemical properties of nanomaterials are different from those of macroscopic substances, showing unique properties in optics, electricity, magnetism, biology, and other aspects. Nanomaterials have been extensively applied in the research of biosensors, greatly promoting the development of biosensors. Nano-functionalized materials are used as electroactive markers (Xiao et al., 2020), enrichment materials (Briceno et al., 2019), signal carriers (Gao et al., 2018), and catalysts (Xie et al., 2019a) for signal amplification.

In recent years, nanomaterials have been introduced into sensors to manufacture a large number of high-sensitivity sensing systems, which have excellent performance and long-term stability (Gao et al., 2018). Shen et al. combined sensors with silicon nanowires to develop a real-time bioaerosol sensing system, which can observe the conductance changes of $\mathrm{H} 3 \mathrm{~N} 2$ viruses in a few seconds (Shen et al., 2011). The hybrid structure of nanomaterials has attracted much attention due to its synergistic amplification effects. A platinum nanoparticle hybrid ZIF-8 composite biosensor can detect Salmonella at 11 $\mathrm{CFU} / \mathrm{mL}$ (Wang et al., 2020a). The gold nanoparticle hybrid fullerene nanoparticle/nitrogen-doped graphene nanosheet biosensor can detect MTB at $3 \mathrm{fM}$ (Bai et al., 2019).

\subsubsection{Enzyme catalysis amplification technology}

Enzymes are organic macromolecules with high selectivity and catalytic ability produced by living organisms. In biological analysis, enzymes are one of the most common signal markers. The catalytic effect of enzymes on substrates can transform the biochemical signals that are difficult to be detected into optical or electrical signals; meanwhile, the biological signals can be amplified to improve the detection sensitivity. Biological enzymes are subject to certain restrictions in application due to their high price and easy inactivation. In recent years, researchers have discovered that immobilizing enzymes on the surface of nanomaterials can not only increase the amount of enzyme immobilized, but also immobilize multiple enzymes at the same time, realizing the further amplification of the detection signal, and constructing nanocatalysts with mimic enzyme properties. Enzyme catalysis amplification technology has been used in the development of biosensors for its low cost, stable performance, and adjustable catalytic activity (Xie et al., 2019a).

\subsubsection{Nucleic acid-based amplification technology}

Nucleic acid-based amplification technology is an amplification method that can transform a small number of nucleic acid molecules into a large number of nucleic acid amplification products. It is mostly used to detect specific accounting fragments of airborne microorganisms. Nucleic acid amplification technology can be divided into nonisothermal amplification technology (polymerase chain reaction [PCR] technology) and isothermal amplification technology (such as chain replacement amplification technology and rolling circle amplification technology) depending on reaction conditions. Zhang developed a biosensor based on Exonuclease III (Exo III)-assisted target recovery, which can recognize hybrid double strands and selectively digest DNA capture probes. This process improved the sensor's sensitivity, and it can detect 20 CFU/mL MTB (Zhang et al. 2019b). Liu et al. improved the silicon photonic microcircle sensor using recombinase polymerase amplification technology, which increased the detection sensitivity of the sensor by three times (Liu et al., 2018c).

\section{Application of sensors to detect airborne microorganisms}

Biosensors have made considerable progress in the detection of airborne microorganisms. Tables 3, 4, and 5 summarize the applications of biosensors in the detection of airborne viruses, bacteria, and other microorganisms, respectively, and present the sensor types, sample types, detection concentration range, detection limit, response time and detection target for the detection of different microorganisms. Figure 3 summarizes the response time and detection limit of several common sensors for the detection of specific substances of airborne microorganisms. Thus, the response time of the sensor is mostly concentrated in the minute level, and the detection limit for specific substances can be as low as " $\mathrm{zM}$ " $\left(10^{-21} \mathrm{~mol} / \mathrm{L}\right)$. Compared with other airborne microorganisms, the virus has a lower detection limit and a shorter response time. Electrochemical sensors have been extensively used, with detection limits spanning multiple orders of magnitude of dynamic range, and can quickly detect low-concentration microorganisms.

\section{Optimization of biosensor performance}

In recent years, some new technologies have been used to optimize biosensors to detect airborne microorganisms, and the performance and efficiency of the biosensors have improved. For example, air sampling technology is used to solve of low content of microorganisms to be tested in environmental aerosol samples and improve the sensitivity of the biosensor. Purification and separation technology can improve the anti-infection ability of biosensors and solve the problems of excessive impurities in environmental aerosol samples. Microfluidic technology can 


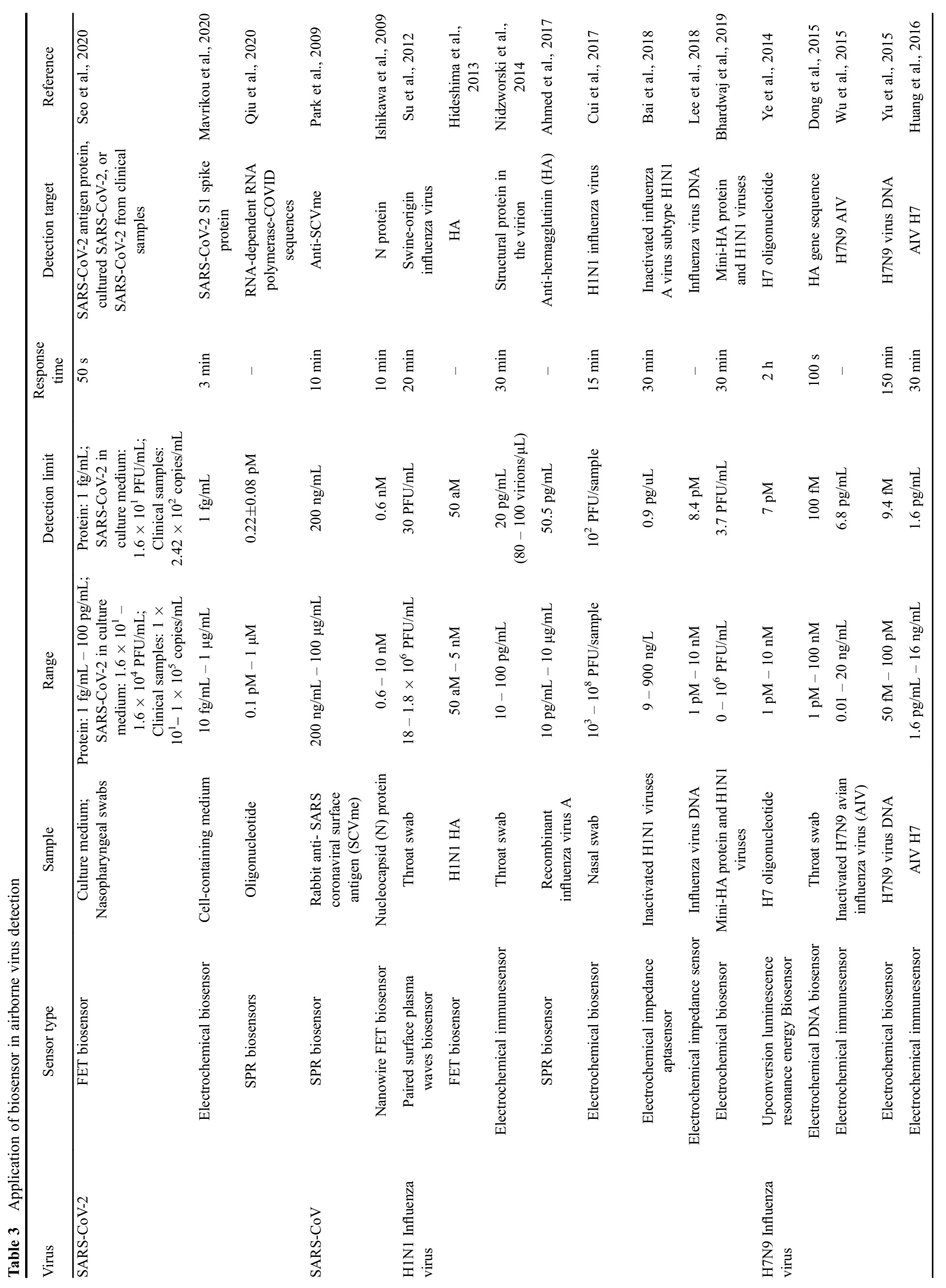




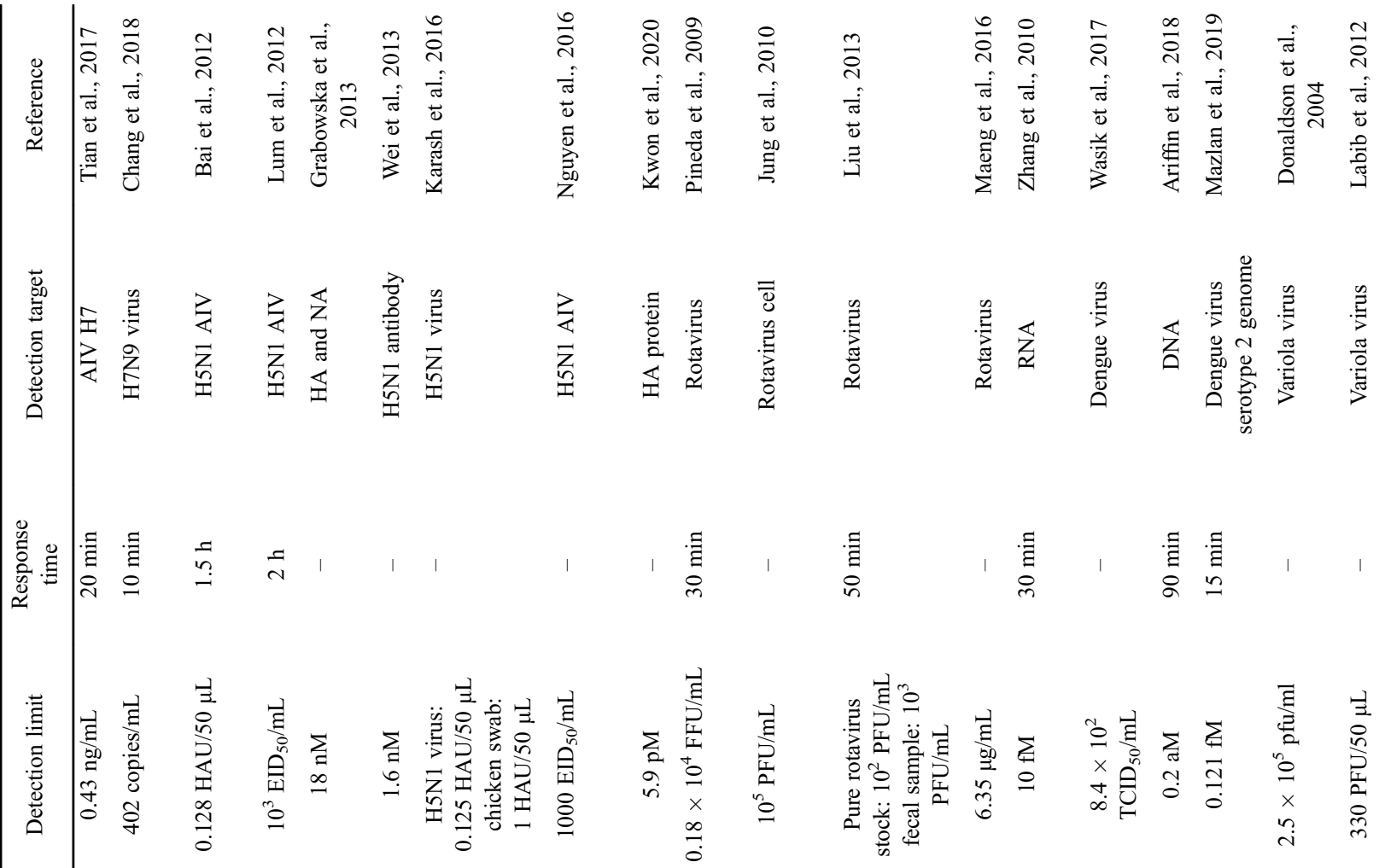

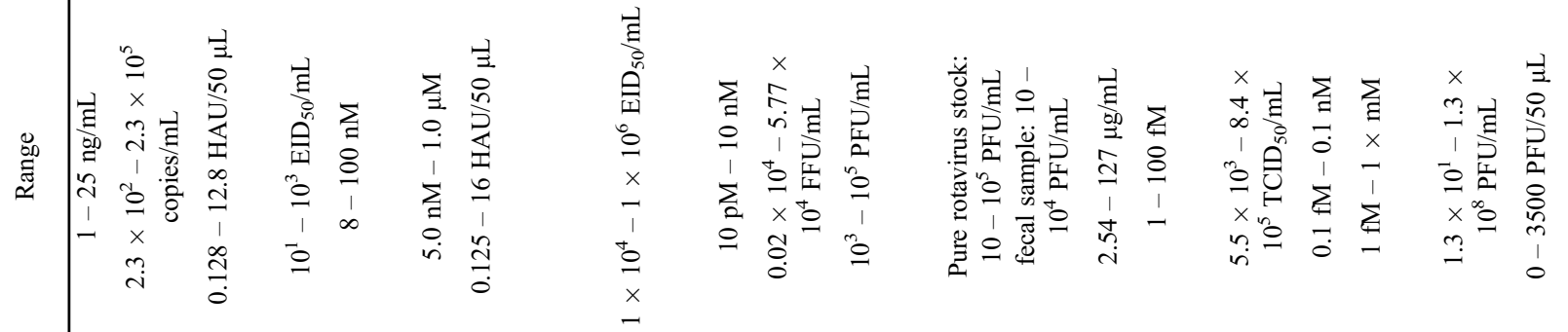

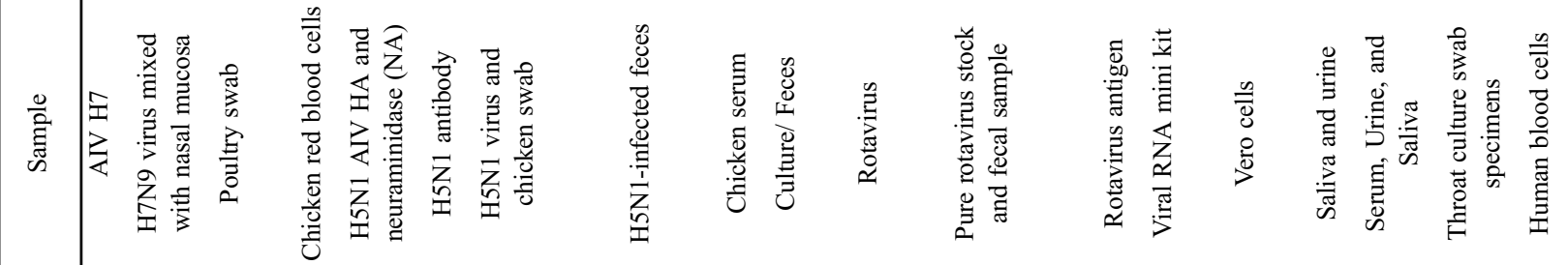
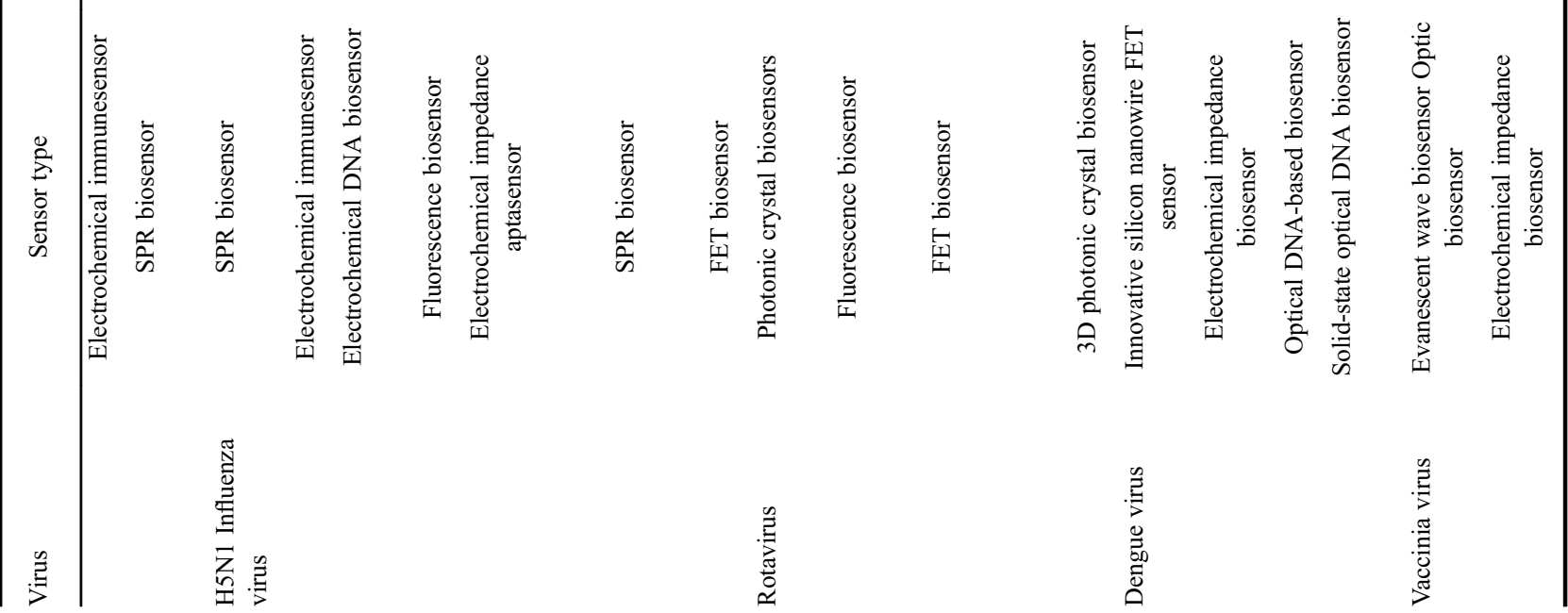


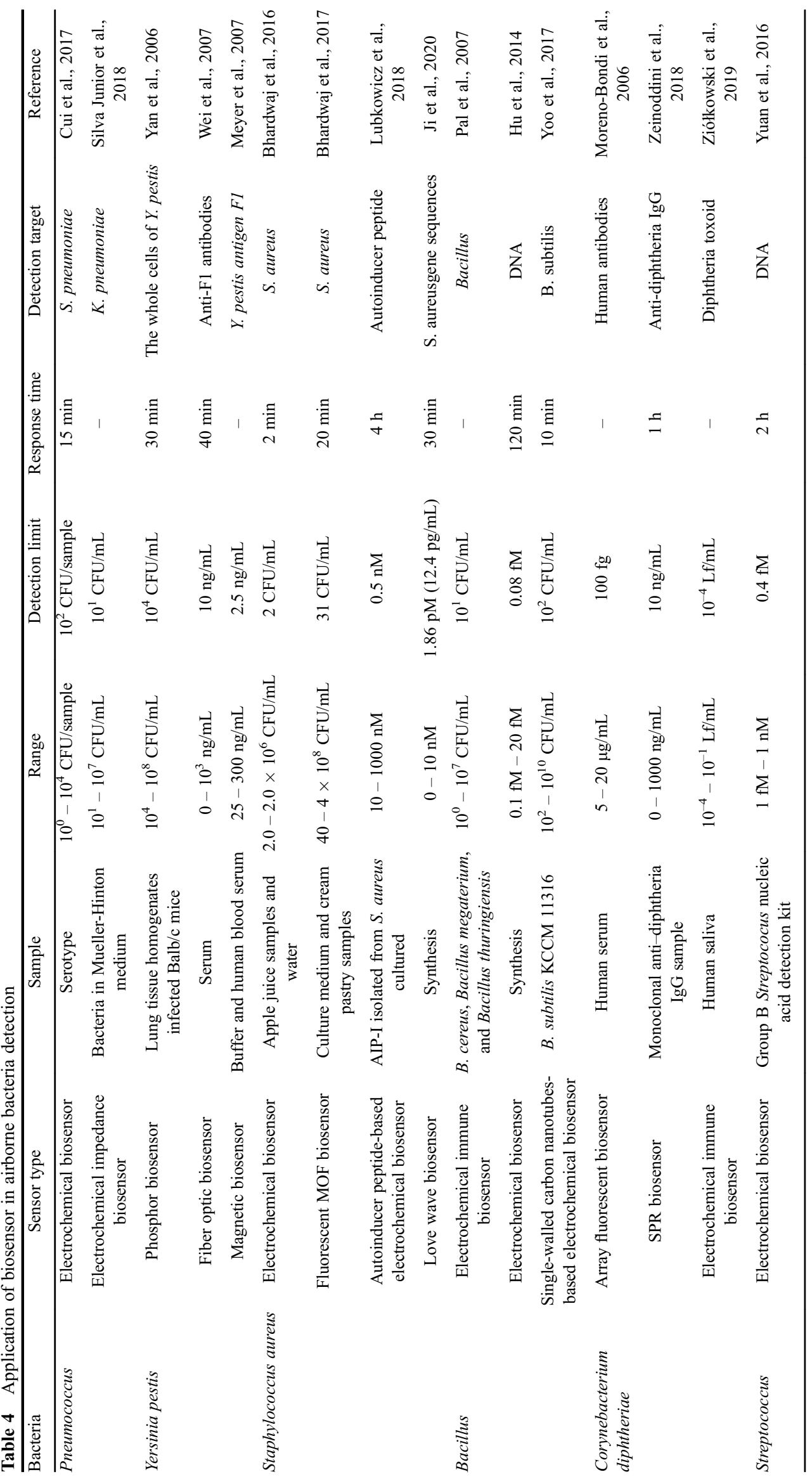




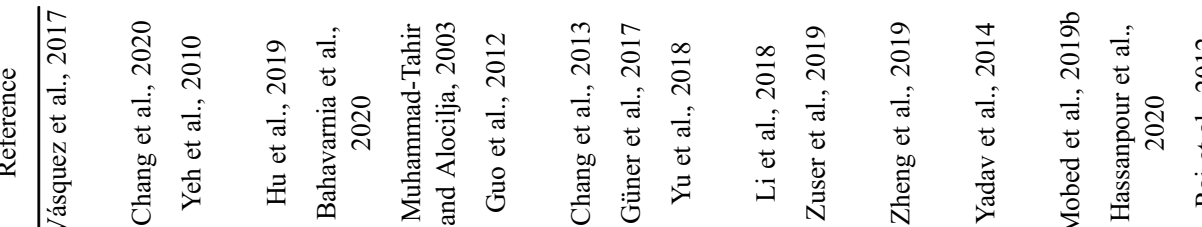

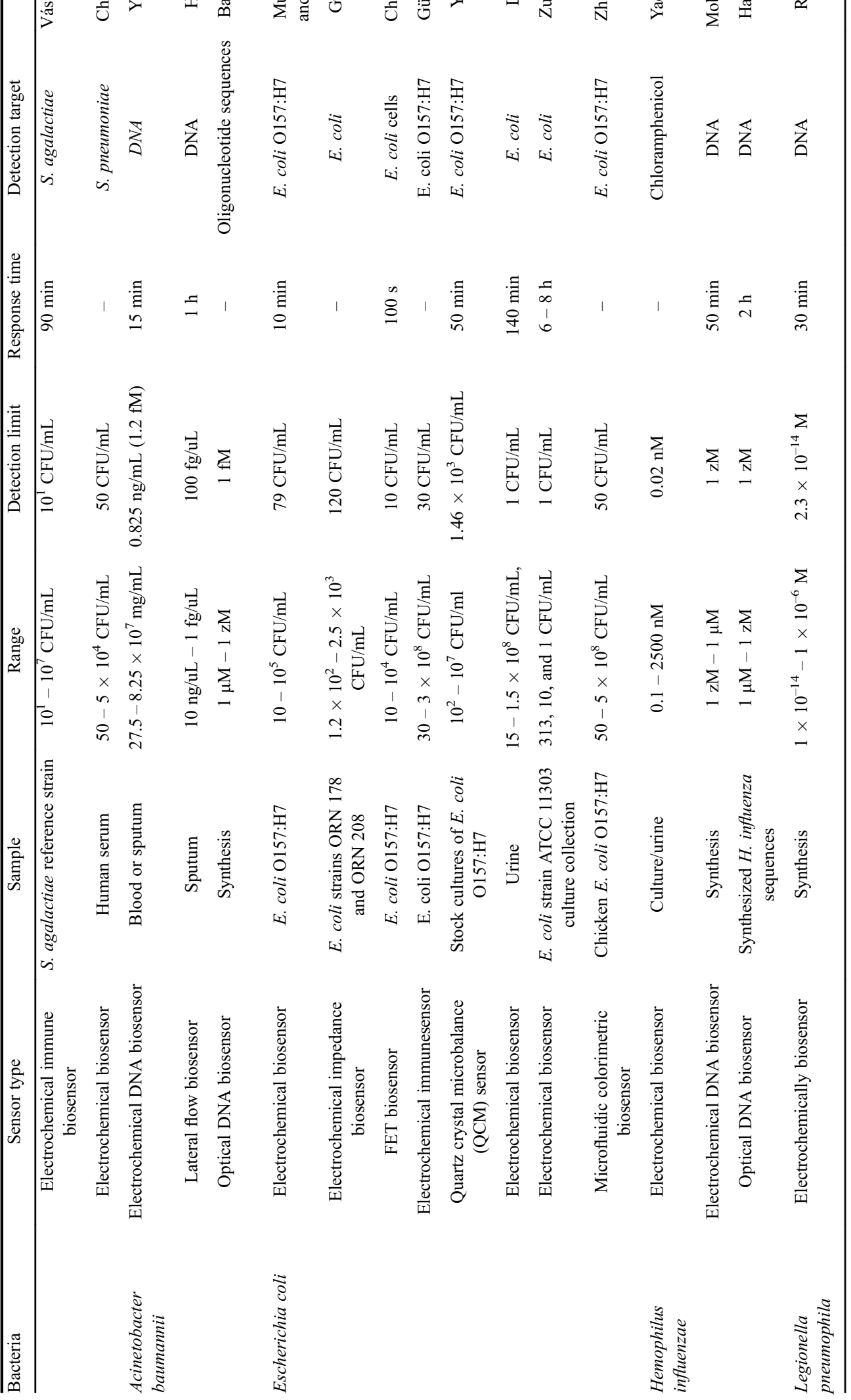




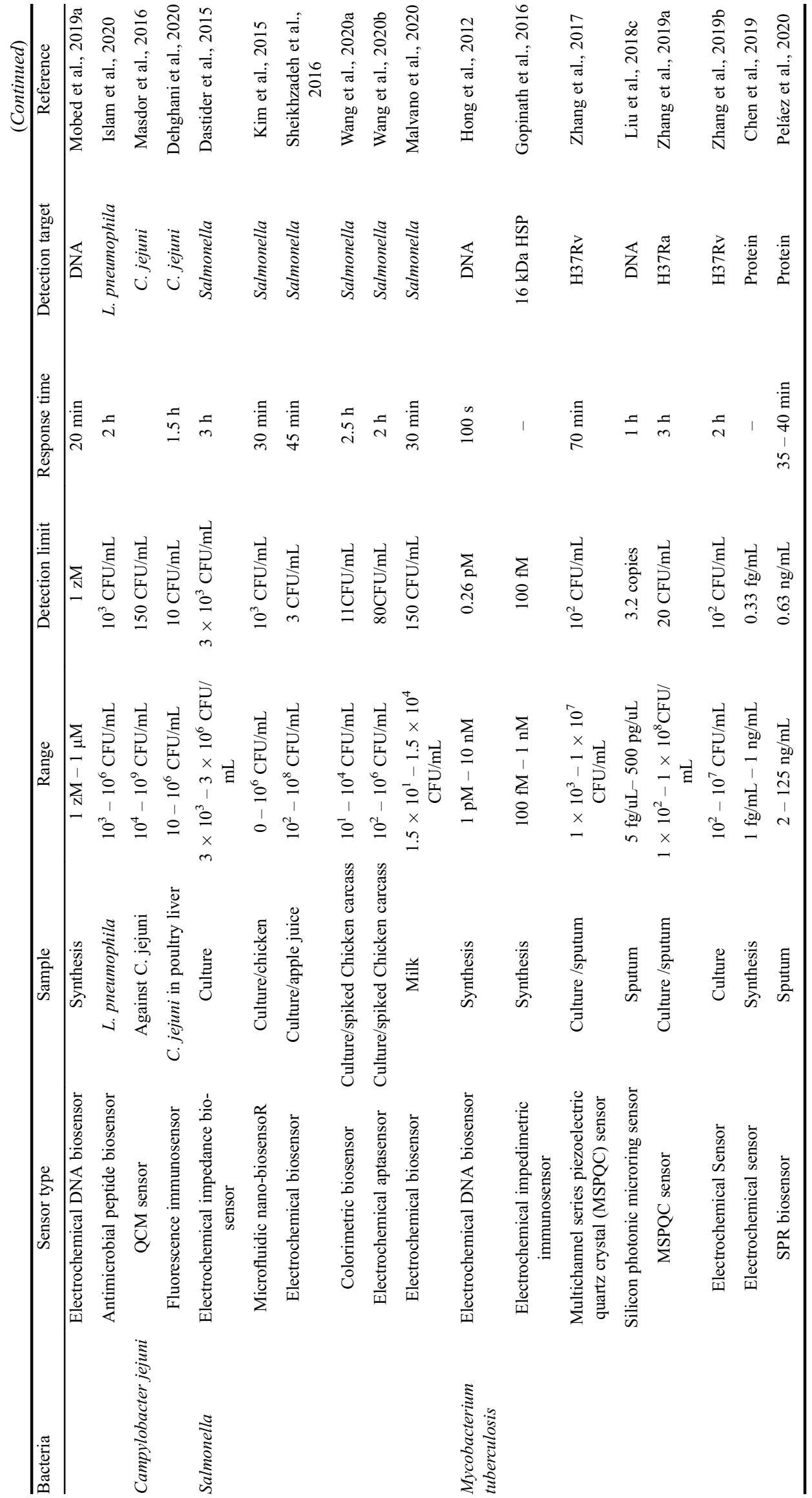


Table 5 Application of biosensor in airborne bio-substances detection

\begin{tabular}{|c|c|c|c|c|c|c|c|}
\hline Bio-substance & Sensor type & Sample & Range & Detection limit & $\begin{array}{l}\text { Response } \\
\text { time }\end{array}$ & Detection target & Reference \\
\hline $\begin{array}{l}\text { Aspergillus } \\
\text { flavus }\end{array}$ & $\begin{array}{c}\text { Electrochemical DNA } \\
\text { biosensor }\end{array}$ & $\begin{array}{l}\text { Aflatoxin B1 in } \\
\text { pistachio nuts }\end{array}$ & $1 \mathrm{nM}-10 \mu \mathrm{M}$ & $0.55 \mathrm{nM}$ & $4 \mathrm{~h}$ & $\overline{D N A}$ & $\begin{array}{c}\text { Sedighi- } \\
\text { Khavidak et al., } \\
2017\end{array}$ \\
\hline $\begin{array}{l}\text { Aspergillus } \\
\text { niger }\end{array}$ & Cantilever sensor & Fungal strain $A$. niger & - & $10^{3} \mathrm{CFU} / \mathrm{mL}$ & $4 \mathrm{~h}$ & Fungal spores & $\begin{array}{c}\text { Nugaeva et al., } \\
2007\end{array}$ \\
\hline \multirow[t]{6}{*}{ Mycoplasma } & Cantilever Sensors & Cell culture & $10^{3}-10^{7} \mathrm{CFU} / \mathrm{mL}$ & $10^{3} \mathrm{CFU} / \mathrm{mL}$ & Less than $1 \mathrm{~h}$ & Mycoplasma & Xu et al., 2010 \\
\hline & $\begin{array}{l}\text { Electrochemical gene } \\
\text { sensor }\end{array}$ & Synthesis & $0.1 \mathrm{pM}-20 \mathrm{nM}$ & $0.03 \mathrm{pM}$ & $2 \mathrm{~h}$ & DNA & Liu et al., 2016 \\
\hline & Fluorescence biosensor & Sheep serum & $10^{2}-10^{6}$ copies $/ \mu \mathrm{L}$ & 1.042 copies $/ \mu \mathrm{L}$ & $\begin{array}{l}\text { Less than } \\
15 \text { min }\end{array}$ & $\begin{array}{c}\text { Mycoplasma } \\
\text { ovipneumoniae }\end{array}$ & Chen et al., 2017 \\
\hline & Lateral flow biosensor & $\begin{array}{l}\text { Oropharyngeal } \\
\text { swab specimens }\end{array}$ & $60 \mathrm{fg} / \mathrm{uL}-60 \mathrm{ng} / \mathrm{uL}$ & $600 \mathrm{fg} / \mathrm{uL}$ & $1 \mathrm{~h}$ & DNA & $\begin{array}{l}\text { Wang et al., } \\
2019 \mathrm{~b}\end{array}$ \\
\hline & Lateral flow biosensor & $\begin{array}{l}\text { Oropharyngeal } \\
\text { Swab specimens }\end{array}$ & $5 \mathrm{fg} / \mathrm{uL}-5 \mathrm{ng} / \mathrm{uL}$ & $50 \mathrm{fg} / \mathrm{uL}$ & $1 \mathrm{~h}$ & DNA & $\begin{array}{l}\text { Wang et al., } \\
2019 \mathrm{c}\end{array}$ \\
\hline & Fluorescence biosensor & Human saliva & $5-300 \mathrm{nM}$ & $3.96 \mathrm{~nm}$ & $10 \mathrm{~min}$ & DNA & Li et al., 2019 \\
\hline Rickettsia & Optical biosensor & $\begin{array}{l}\text { Blood plasma/Liver } \\
\text { biopsy samples }\end{array}$ & $\begin{array}{c}5 \times 10^{1}-5 \times 10^{4} \\
\text { copies/reaction }\end{array}$ & $\begin{array}{l}5 \times 10^{1} \text { copies/ } \\
\text { reaction }\end{array}$ & $20 \mathrm{~min}$ & DNA & Koo et al., 2018 \\
\hline \multirow[t]{2}{*}{ Chlamydia } & Optical DNA biosensor & Human urine & $0.25-20 \mathrm{nM}$ & $0.25 \mathrm{nM}$ & - & DNA & Parab et al., 2010 \\
\hline & Nanoplasmonic biosensor & Culture/ Urine & $10^{1}-10^{7} \mathrm{CFU} / \mathrm{mL}$ & $300 \mathrm{CFU} / \mathrm{mL}$ & - & $\begin{array}{l}\text { Chlamydia } \\
\text { trachomatis }\end{array}$ & Soler et al., 2017 \\
\hline $\begin{array}{l}\text { Leishmania } \\
\text { spp }\end{array}$ & $\begin{array}{c}\text { Electrochemical DNA } \\
\text { biosensor }\end{array}$ & $\begin{array}{l}\text { Genomic sequence of } \\
\text { Leishmania major }\end{array}$ & $0.5-20 \mathrm{ng} / \mu \mathrm{L}$ & $0.07 \mathrm{ng} / \mu \mathrm{L}$ & - & DNA & $\begin{array}{l}\text { Moradi et al., } \\
\quad 2016\end{array}$ \\
\hline
\end{tabular}

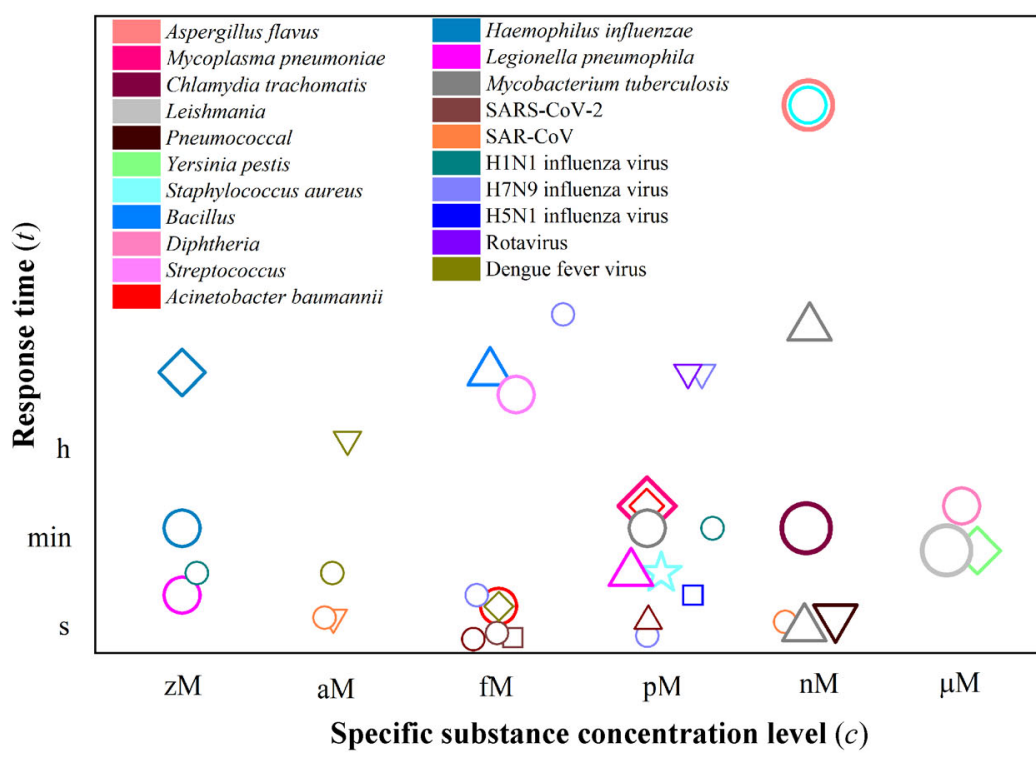

O - Electrochemical biosensor

$\square$-Field effect transistor based biosensor

it - Piezoelectric Biosensors

$\nabla$-Fluorescent biosensor

$\Delta$-Plasmon surface resonance biosensor

$\diamond$-Colorimetric biosensor

(Symbols from small to large represent: viruses, bacteria and other microorganisms)

Fig. 3 Performance chart of airborne microbial-specific substances of common biosensors.

reduce sample consumption, reduce the size of detection equipment, and improve detection anti-interference ability; it is flexible and portable and convenient for field operations. Multiple detection technology can perform multiple detections at the same time, thereby improving the detection efficiency of biosensors. Smart devices can improve the visual operation and remote operability of the biosensors. 


\subsection{Air sampling technology}

Although clinical samples such as nasopharyngeal swabs can be used for detection, traditional sampling methods can make patients feel uncomfortable and cause sneezing to produce aerosols, which can cause potential health risks (Cui and Zhou, 2020). At present, biosensors use air sampling systems to directly detect air samples. For infectious disease hotspots, the rapid detection of airborne microorganisms in air samples is necessary, and air sampling is often the first critical step (Shen et al., 2012). Wen et al. developed an air sampling method for Gramnegative bacterial marker endotoxin, optimized the analysis method based on the limulus reagent test (Wen et al., 2017), and detected 37.9-97.6 EU/ $\mathrm{m}^{3}$ endotoxin in the air of a university campus (Liu et al., 2018a). Zheng et al. used an exhaled air condensing device to obtain $300 \mu \mathrm{L}$ of air sample within $3 \mathrm{~min}$, and combined it with isothermal amplification technology to successfully detect seven airborne microorganisms from exhaled breath (Zheng et al., 2018). Rufino de Sousa et al. developed a large-scale electrostatic air sampler with good air filtration and sample treatment capabilities, and successfully detected Bacillus Calmette-Guerin vaccine of about 11 CFU/L-air and MTB of $46 \mathrm{CFU} / \mathrm{L}$-air within $15 \mathrm{~min}$ (Rufino de Sousa et al., 2020). Meanwhile, there are other applications for the direct detection of air samples. Bhattacharyya et al. built a titanium dioxide nanotube array sensing platform for the electrochemical detection of tuberculosis volatile organic compound biomarkers, which can detect $0.12 \mathrm{mg} / \mathrm{m}^{3}$ of methyl anisate (Bhattacharyya et al., 2016).

\subsection{Purification and separation technology}

The actual sample has impurity interference and the content of microorganisms in environmental aerosols is low. Directly collecting airborne microorganisms can be very challenging. Therefore, the samples for sensor detection must be preprocessed. Immunomagnetic separation has been extensively used in sample pretreatment. However, this method has shortcomings such as high requirements and low efficiency, that limit its application. Wang et al. used a magnetic grid separation column without any pre-enrichment of bacteria to complete the separation of $70 \%$ of target Salmonella cells in a $50 \mathrm{~mL}$ bacterial sample in $2.5 \mathrm{~h}$, greatly improving the sensitivity of the sensor (Wang et al., 2020a). Song et al. proposed an optimized collection and detection scheme for complex air samples, which can break the wall of airborne microorganisms without destroying the internal structure, thereby improving the detection efficiency (Song et al., 2020). Briceno et al. added a magnetic field to the nanoparticles combined with MTB to achieve separation and enrichment, and the concentration rate of MTB could reach $47 \%$, without using any expensive consumables and equipment (Briceno et al., 2019).

\subsection{Microfluidic technology}

Existing sensors mostly use the drip method to measure samples, making the loading and processing of samples difficult to control. This method is susceptible to interference from external physical factors such as light, humidity, and temperature, resulting in inaccurate measurement and poor sensing stability. Microfluidic technology integrates sample preparation, reagent manipulation, biological reactions, and detection steps on a unique platform, which can simplify complex analysis schemes and reduce sample volume, detection time, and reagent costs (Nasseri et al., 2018). Khan et al. integrated graphene and microfluidic devices to enhance the sensing performance, such as detection limit and sensitivity and continuous monitoring; the detection limit for thrombin reached 2.6 pM (Khan et al., 2020). Xie et al. used a highthroughput microfluidic chip to construct an electrical impedance sensor, and successfully distinguished different forms of yeast, which can be used as a rapid analysis technique to airborne microorganisms (Xie et al., 2019b).

\subsection{Multiple detection technology}

To improve the detection efficiency of biosensors and the portability of outdoor operations, multiple samples or multiple target microorganisms need to be detected at the same time to increase practicability and flexibility (Liu et al., 2018b). Liu et al. combined four micro-ring sensors to realize real-time measurement and multiplexing of four samples, greatly improving the detection speed (Liu et al., 2018c). Kumar et al. used peptide nucleic acids to induce color changes caused by aggregation of gold nanoparticles, which can be used to simultaneously detect multiple influenza viruses (Kumar et al., 2020).

\subsection{Smart device linkage}

The combination of biosensors and smart devices can make them flexible and portable; capable of real-time, continuous, and rapid detection; and has unique advantages such as miniaturization, high sensitivity, and absence of tags (Yang and Gao, 2019; Xing et al., 2020). The introduction of smart devices has greatly improved microorganism detection and provided convenient data processing and transmission for demonstration purposes (Nasseri et al., 2018). Mavrikou et al. combined a biosensor with a customized portable readout device operated by a smart phone/tablet computer for the portable detection of the new coronavirus spike protein within 3 min, with a detection limit of $1 \mathrm{fg} / \mathrm{mL}$ (Mavrikou et al., 2020). Zheng et al. developed a new type of biosensor and 
used a smartphone imaging APP to monitor the color changes of AuNPs to determine the number of bacteria. The detection limit for Escherichia coli in chicken samples was $50 \mathrm{CFU} / \mathrm{mL}$ (Zheng et al., 2019).

\section{$5 \quad$ Future perspectives}

The current recurrence of airborne infectious diseases is not optimistic, and the COVID-19 pandemic threatens to interfere with public health services. Reversing the recent progress in reducing the burden of airborne infectious diseases will lead to a reduction in the detection of infectious diseases and an increase in deaths. Therefore, rapid detection and point-of-care (POC) analysis of airborne microorganisms that cause these diseases are important. Among the various methods used to detect airborne microorganisms, biosensor technology is at the forefront of POC device development. In recent years, scientists have conducted extensive research on biosensor technology. Some biosensors have been gradually used to detect microorganisms in air, and good results have been achieved. However, some challenges in sensors need to be further resolved in the future:

1) The detection of air samples requires further research. Most of the biosensor samples used for the detection of microorganisms in air are tested under laboratory conditions, and the test samples are usually limited to ideal samples, such as recombinant proteins or cell culture fluids, which are often different from actual samples.

2) An intelligent integrated system of sensor air collection and detection should be developed. Such a system integrates air collection, sample pretreatment, specific detection, and other steps. It also minimizes errors caused by manual operation, improves detection efficiency, and realizes fast and portable detection. An integrated system is essential to determine whether the sensor can leave of the laboratory to be tested.

3) Reduce costs, improve stability, and realize commercial production. Given the current outbreak of global infectious diseases, to expand the detection range, costs should be reduced, standardized sensor preparation and functionalization should be carried out, and more sensor characterization methods, such as expressing sensor detection performance in advance through the working characteristic curve, should be developed. Thus, largescale commercial production can be realized.

4) Optimize the repeatability of the sensor. Given that the recognition and binding of biomolecules is often irreversible, most existing sensors are disposable products, and rebirth is difficult to achieve. The current rebirth effect is also uneven, and there is no unified standard that defines it. This is an important reason for limiting the large-scale application of sensors.

5) Further improve the specificity and sensitivity of the sensor. As a result of the low concentration of air microorganisms, detection is difficult, which affects the detection sensitivity of the sensor, and impurities are likely to cross-react and affect the detection specificity. New and more sensitive specific biological recognition elements must be developed.

Acknowledgements This study was supported by the National Natural Science Foundation of China (Grant No. 51678402) and the Tianjin New Crown Epidemic Emergency Project (No. 20ZXGBSY00100).

\section{References}

Ahmed S R, Kim J, Tran V T, Suzuki T, Neethirajan S, Lee J, Park E Y (2017). In situ self-assembly of gold nanoparticles on hydrophilic and hydrophobic substrates for influenza virus-sensing platform. Scientific Reports, 7(1): 44495

Ariffin E Y, Tan L L, Karim N H A, Heng L Y (2018). Optical DNA biosensor based on square-planar ethyl piperidine substituted nickel (II) salphen complex for dengue virus detection. Sensors (Basel), 18 (4): 1173

Bahavarnia F, Mobed A, Hasanzadeh M, Saadati A, Hassanpour S, Mokhtarzadeh A (2020). Bio-assay of Acintobacter baumannii using DNA conjugated with gold nano-star: A new platform for microorganism analysis. Enzyme and Microbial Technology, 133: 109466

Bai C, Lu Z, Jiang H, Yang Z, Liu X, Ding H, Li H, Dong J, Huang A, Fang T, Jiang Y, Zhu L, Lou X, Li S, Shao N (2018). Aptamer selection and application in multivalent binding-based electrical impedance detection of inactivated H1N1 virus. Biosensors \& Bioelectronics, 110: 162-167

Bai H, Wang R, Hargis B, Lu H, Li Y (2012). A SPR aptasensor for detection of avian influenza virus H5N1. Sensors (Basel), 12(9): 12506-12518

Bai L, Chen Y, Liu X, Zhou J, Cao J, Hou L, Guo S (2019). Ultrasensitive electrochemical detection of Mycobacterium tuberculosis IS6110 fragment using gold nanoparticles decorated fullerene nanoparticles/nitrogen-doped graphene nanosheet as signal tags. Analytica Chimica Acta, 1080: 75-83

Bhardwaj J, Chaudhary N, Kim H, Jang J (2019). Subtyping of influenza A H1N1 virus using a label-free electrochemical biosensor based on the DNA aptamer targeting the stem region of HA protein. Analytica Chimica Acta, 1064: 94-103

Bhardwaj N, Bhardwaj S K, Mehta J, Kim K H, Deep A (2017). MOFbacteriophage biosensor for highly sensitive and specific detection of Staphylococcus aureus. ACS Applied Materials \& Interfaces, 9(39): 33589-33598

Bhardwaj N, Bhardwaj S K, Mehta J, Mohanta G C, Deep A (2016). Bacteriophage immobilized graphene electrodes for impedimetric sensing of bacteria (Staphylococcus arlettae). Analytical Biochemistry, 505: 18-25

Bhattacharyya D, Smith Y R, Mohanty S K, Misra M (2016). Titania nanotube array sensor for electrochemical detection of four predominate Tuberculosis volatile biomarkers. Journal of the Electrochemical Society, 163(6): B206

Brenner D J, Hall E J (2007). Computed tomography — An increasing 
source of radiation exposure. New England Journal of Medicine, 357 (22): 2277-2284

Briceno R K, Sergent S R, Benites S M, Alocilja E C (2019). Nanoparticle-based biosensing assay for universally accessible lowcost TB detection with comparable sensitivity as culture. Diagnostics (Basel), 9(4): 222

Cesewski E, Johnson B N (2020). Electrochemical biosensors for pathogen detection. Biosensors \& Bioelectronics, 159: 112214

Chang J, Mao S, Zhang Y, Cui S, Zhou G, Wu X, Yang C H, Chen J (2013). Ultrasonic-assisted self-assembly of monolayer graphene oxide for rapid detection of Escherichia coli bacteria. Nanoscale, 5 (9): 3620-3626

Chang P H, Weng C C, Li B R, Li Y K (2020). An antifouling peptidebased biosensor for determination of Streptococcus pneumonia markers in human serum. Biosensors \& Bioelectronics, 151: 111969

Chang Y F, Wang W H, Hong Y W, Yuan R Y, Chen K H, Huang Y W, Lu P L, Chen Y H, Chen Y M A, Su L C, Wang S F (2018). Simple strategy for rapid and sensitive detection of avian influenza A H7N9 virus based on intensity-modulated SPR biosensor and new generated antibody. Analytical Chemistry, 90(3): 1861-1869

Chen Q, Zhang L, Jiang F, Wang B, Lv T, Zeng Z, Wu W, Sun S (2017). $\mathrm{MnO}_{2}$ microsphere absorbing Cy5-labeled single strand DNA probe serving as powerful biosensor for effective detection of mycoplasma ovipneumoniae. Sensors and Actuators. B, Chemical, 244: 11381144

Chen Y, Liu X, Guo S, Cao J, Zhou J, Zou J, Bai L (2019). A sandwichtype electrochemical aptasensor for Mycobacterium tuberculosis MPT64 antigen detection using C60NPs decorated N-CNTs/GO nanocomposite coupled with conductive PEI-functionalized metalorganic framework. Biomaterials, 216: 119253

Cui F, Zhou H S (2020). Diagnostic methods and potential portable biosensors for coronavirus disease 2019. Biosensors \& Bioelectronics, 165: 112349

Cui X, Das A, Dhawane A N, Sweeney J, Zhang X, Chivukula V, Iyer S $S$ (2017). Highly specific and rapid glycan based amperometric detection of influenza viruses. Chemical Science (Cambridge), 8(5): 3628-3634

Dastider S G, Barizuddin S, Yuksek N S, Dweik M, Almasri M F (2015). Efficient and rapid detection of Salmonella using microfluidic impedance based sensing. Journal of Sensors, 8: 293461

Dehghani Z, Mohammadnejad J, Hosseini M, Bakhshi B, Rezayan A H (2020). Whole cell FRET immunosensor based on graphene oxide and graphene dot for Campylobacter jejuni detection. Food Chemistry, 309: 125690

Després V R, Huffman J A, Burrows S M, Hoose C, Safatov A S, Buryak G, Fröhlich-Nowoisky J, Elbert W, Andreae M O, Pöschl U, Jaenicke R (2012). Primary biological aerosol particles in the atmosphere: A review. Tellus B: Chemical and Physical Meteorology, 64(1): 15598

Donaldson K A, Kramer M F, Lim D V (2004). A rapid detection method for Vaccinia virus, the surrogate for smallpox virus. Biosensors \& Bioelectronics, 20(2): 322-327

Dong S, Zhao R, Zhu J, Lu X, Li Y, Qiu S, Jia L, Jiao X, Song S, Fan C, Hao R, Song H (2015). Electrochemical DNA biosensor based on a tetrahedral nanostructure probe for the detection of avian influenza A (H7N9) virus. ACS Applied Materials \& Interfaces, 7(16): 88348842
Doremalen N, Bushmaker T, Morris D H, Holbrook M G, Gamble A, Williamson B N, Tamin A, Harcourt J L, Thornburg N J, Gerber S I, Lloyd-Smith J O, Wit E, Munster V J (2020). Aerosol and surface stability of SARS-CoV-2 as compared with SARS-CoV-1. The New England Journal of Medicine, 382(16): 1564-1567

Eddabra R, Ait Benhassou H (2018). Rapid molecular assays for detection of tuberculosis. Pneumonia, 10(1): 4

Freije C A, Myhrvold C, Boehm C K, Lin A E, Welch N L, Carter A, Metsky H C, Luo C Y, Abudayyeh O O, Gootenberg J S, Yozwiak N L, Zhang F, Sabeti P C (2019). Programmable inhibition and detection of RNA viruses using Cas13. Molecular Cell, 76(5): 826837.e11

Fronczek C F, Yoon J Y (2015). Biosensors for monitoring airborne pathogens. Journal of Laboratory Automation, 20(4): 390-410

Gao A, Chen S, Wang Y, Li T (2018). Silicon nanowire field-effecttransistor-based biosensor for biomedical applications. Sensors and Materials, 30(8): 1619-1628

Gopinath S C B, Perumal V, Kumaresan R, Lakshmipriya T, Rajintraprasad H, Rao B S, Arshad M K Md, Chen Y, Kotani N, Hashim U (2016). Nanogapped impedimetric immunosensor for the detection of $16 \mathrm{kDa}$ heat shock protein against Mycobacterium tuberculosis. Mikrochimica Acta, 183(10): 2697-2703

Grabowska I, Malecka K, Stachyra A, Gora-Sochacka A, Sirko A, Zagorski-Ostoja W, Radecka H, Radecki J (2013). Single electrode genosensor for simultaneous determination of sequences encoding hemagglutinin and neuraminidase of avian influenza virus type H5N1. Analytical Chemistry, 85(21): 10167-10173

Güner A, Cevik E, Senel M, Alpsoy L (2017). An electrochemical immunosensor for sensitive detection of Escherichia coli O157:H7 by using chitosan, MWCNT, polypyrrole with gold nanoparticles hybrid sensing platform. Food Chemistry, 229: 358-365

Guo X, Kulkarni A, Doepke A, Halsall H B, Iyer S, Heineman W R (2012). Carbohydrate-based label-free detection of Escherichia coli ORN 178 using electrochemical impedance spectroscopy. Analytical Chemistry, 84(1): 241-246

Gupta S, Kakkar V (2018). Recent technological advancements in tuberculosis diagnostics: A review. Biosensors \& Bioelectronics, 115: $14-29$

Hassanpour S, Saadati A, Hasanzadeh M (2020). pDNA conjugated with citrate capped silver nanoparticles towards ultrasensitive bio-assay of Haemophilus influenza in human biofluids: A novel optical biosensor. Journal of Pharmaceutical and Biomedical Analysis, 180: 113050

Hideshima S, Hinou H, Ebihara D, Sato R, Kuroiwa S, Nakanishi T, Nishimura S I, Osaka T (2013). Attomolar detection of influenza A virus hemagglutinin human $\mathrm{H} 1$ and avian $\mathrm{H} 5$ using glycan-blotted field effect transistor biosensor. Analytical Chemistry, 85(12): 56415644

Hoehl S, Rabenau H, Berger A, Kortenbusch M, Cinatl J, Bojkova D, Behrens P, Böddinghaus B, Götsch U, Naujoks F, Neumann P, Schork J, Tiarks-Jungk, P, Walczok A, Eickmann M, Vehreschild M J G T, Kann G, Wolf T, Gottschalk R, Ciesek S (2020). Evidence of SARS-CoV-2 infection in returning travelers from Wuhan, China. The New England Journal of Medicine, 382(13): 1278-1280

Hong G, Liu Y, Chen W, Weng S, Liu Q, Liu A, Zheng D, Lin X (2012). A sandwich-type DNA electrochemical biosensor for hairpin-stem- 
loop structure based on multistep temperature-controlling method. International Journal of Nanomedicine, 7: 4953-4960

Hu S, Niu L, Zhao F, Yan L, Nong J, Wang C, Gao N, Zhu X, Wu L, Bo T, Wang H, Gu J (2019). Identification of Acinetobacter baumannii and its carbapenem-resistant gene blaOXA-23-like by multiple cross displacement amplification combined with lateral flow biosensor. Scientific Reports, 9(1): 17888

Hu Y, Xu X, Liu Q, Wang L, Lin Z, Chen G (2014). Ultrasensitive electrochemical biosensor for detection of DNA from Bacillus subtilis by coupling target-induced strand displacement and nicking endonuclease signal amplification. Analytical Chemistry, 86(17): 8785-8790

Huang J, Xie Z, Xie Z, Luo S, Xie L, Huang L, Fan Q, Zhang Y, Wang S, Zeng $T$ (2016). Silver nanoparticles coated graphene electrochemical sensor for the ultrasensitive analysis of avian influenza virus $\mathrm{H} 7$. Analytica Chimica Acta, 913: 121-127

Hudu S A, Alshrari A S, Syahida A, Sekawi Z (2016). Cell culture, technology: enhancing the culture of diagnosing human diseases. Journal of Clinical and Diagnostic Research: JCDR, 10(3): DE1DE5

Ishikawa F N, Chang H K, Curreli M, Liao H I, Olson C A, Chen P C, Zhang R, Roberts R W, Sun R, Cote R J, Thompson M E, Zhou C (2009). Label-free, electrical detection of the SARS virus N-protein with nanowire biosensors utilizing antibody mimics as capture probes. ACS Nano, 3(5): 1219-1224

Islam M A, Hassen W M, Tayabali A F, Dubowski J J (2020). Antimicrobial warnericin RK peptide functionalized GaAs/AlGaAs biosensor for highly sensitive and selective detection of Legionella pneumophila. Biochemical Engineering Journal, 154: 107435

Ji J, Pang Y, Li D, Wang X, Xu Y, Mu X (2020). Single-layered graphene/Au-nanoparticles-based love wave biosensor for highly sensitive and specific detection of Staphylococcus aureus gene sequences. ACS Applied Materials \& Interfaces, 12(11): 1241712425

Jiang G, Wang C, Song L, Wang X, Zhou Y, Fei C, Liu H (2021). Aerosol transmission, an indispensable route of COVID-19 spread: Case study of a department-store cluster. Frontiers of Environmental Science \& Engineering, 15(3): 46

Jung J H, Cheon D S, Liu F, Lee K B, Seo T S (2010). A graphene oxide based immuno-biosensor for pathogen detection. Angewandte Chemie International Edition, 49(33): 5708-5711

Karash S, Wang R, Kelso L, Lu H, Huang T J, Li Y (2016). Rapid detection of avian influenza virus H5N1 in chicken tracheal samples using an impedance aptasensor with gold nanoparticles for signal amplification. Journal of Virological Methods, 236: 147-156

Khan N I, Mousazadehkasin M, Ghosh S, Tsavalas J G, Song E (2020). An integrated microfluidic platform for selective and real-time detection of thrombin biomarkers using a graphene FET. Analyst (London), 145(13): 4494-4503

Kim G, Moon J H, Moh C Y, Lim J G (2015). A microfluidic nanobiosensor for the detection of pathogenic Salmonella. Biosensors \& Bioelectronics, 67: 243-247

Koo B, Jin C E, Park S Y, Lee T Y, Nam J, Jang Y R, Kim S M, Kim J Y, Kim S H, Shin Y (2018). A rapid bio-optical sensor for diagnosing $Q$ fever in clinical specimens. Journal of Biophotonics, 11(4): e201700167
Kumar N, Bhatia S, Pateriya A K, Sood R, Nagarajan S, Murugkar H V, Kumar S, Singh P, Singh V P (2020). Label-free peptide nucleic acid biosensor for visual detection of multiple strains of influenza A virus suitable for field applications. Analytica Chimica Acta, 1093: 123130

Kwon J, Lee Y, Lee T, Ahn J H (2020). Aptamer-based field-effect transistor for detection of avian influenza virus in chicken serum. Analytical Chemistry, 92(7): 5524-5531

Labib M, Zamay A S, Muharemagic D, Chechik A V, Bell J C, Berezovski M V (2012). Aptamer-based viability impedimetric sensor for viruses. Analytical Chemistry, 84(4): 1813-1816

Lee J, Morita M, Takemura K, Park E Y (2018). A multi-functional gold/ iron-oxide nanoparticle-CNT hybrid nanomaterial as virus DNA sensing platform. Biosensors \& Bioelectronics, 102: 425-431

Li J, Wu J, He Z, Pei H, Xia Q, Wu Q, Ju H (2019). Fast detection of mycoplasma pneumoniae by interaction of tetramolecular G-quadruplex with graphene oxide. Sensors and Actuators. B, Chemical, 290: 41-46

Li Y, Xie G, Qiu J, Zhou D, Gou D, Tao Y, Li Y, Chen H (2018). A new biosensor based on the recognition of phages and the signal amplification of organic-inorganic hybrid nanoflowers for discriminating and quantitating live pathogenic bacteria in urine. Sensors and Actuators. B, Chemical, 258: 803-812

Liu F, Kim Y H, Cheon D S, Seo T S (2013). Micropatterned reduced graphene oxide based field-effect transistor for real-time virus detection. Sensors and Actuators. B, Chemical, 186: 252-257

Liu H, Zhang Z, Wen N, Wang C (2018a). Determination and risk assessment of airborne endotoxin concentrations in a university campus. Journal of Aerosol Science, 115: 146-157

Liu L, Shan D, Zhou X, Shi H, Song B, Falke F, Leinse A, Heideman R (2018b). TriPleX ${ }^{\mathrm{TM}}$ waveguide-based fluorescence biosensor for multichannel environmental contaminants detection. Biosensors \& Bioelectronics, 106: 117-121

Liu L, Xiang G, Jiang D, Du C, Liu C, Huang W, Pu X (2016). Electrochemical gene sensor for Mycoplasma pneumoniae DNA using dual signal amplification via a Pt@Pd nanowire and horse radish peroxidase. Mikrochimica Acta, 183(1): 379-387

Liu Q, Lim B K L, Lim S W, Tang W Y, Gu Z H, Chung J, Park M K, Barkham T (2018c). Label-free, real-time and multiplex detection of Mycobacterium tuberculosis based on silicon photonic microring sensors and asymmetric isothermal amplification technique (SPMSAIA). Sensors and Actuators. B, Chemical, 255: 1595-1603

Lubkowicz D, Ho C L, Hwang I Y, Yew W S, Lee Y S, Chang M W (2018). Reprogramming probiotic Lactobacillus reuteri as a biosensor for Staphylococcus aureus derived AIP-I detection. ACS Synthetic Biology, 7(5): 1229-1237

Lum J, Wang R, Lassiter K, Srinivasan B, Abi-Ghanem D, Berghman L, Hargis B, Tung S, Lu H, Li Y (2012). Rapid detection of avian influenza $\mathrm{H} 5 \mathrm{~N} 1$ virus using impedance measurement of immunoreaction coupled with RBC amplification. Biosensors \& Bioelectronics, 38(1): 67-73

Maeng B, Park Y, Park J (2016). Direct label-free detection of Rotavirus using a hydrogel based nanoporous photonic crystal. RSC Advances, 6(9): 7384-7390

Malvano F, Pilloton R, Albanese D (2020). A novel impedimetric biosensor based on the antimicrobial activity of the peptide nisin for 
the detection of Salmonella spp. Food Chemistry, 325: 126868

Masdor N A, Altintas Z, Tothill I E (2016). Sensitive detection of Campylobacter jejuni using nanoparticles enhanced QCM sensor. Biosensors \& Bioelectronics, 78: 328-336

Mavrikou S, Moschopoulou G, Tsekouras V, Kintzios S (2020). Development of a portable, ultra-rapid and ultra-sensitive cellbased biosensor for the direct detection of the SARS-CoV-2 S1 spike protein antigen. Sensors, 20(11): 3121

Mazlan N F, Tan L L, Karim N H A, Heng L Y, Jamaluddin N D, Yusof N Y M, Quay D H X, Khalid B (2019). Acrylic-based genosensor utilizing metal salphen labeling approach for reflectometric dengue virus detection. Talanta, 198: 358-370

Mekonnen D, Mengist H M, Derbie A, Nibret E, Munshea A, He H L, Li B F, Jin T C (2020). Diagnostic accuracy of serological tests and kinetics of severe acute respiratory syndrome coronavirus 2 antibody: A systematic review and meta-analysis. Reviews in Medical Virology, 2020: e2181 (Published online)

Meyer M H F, Stehr M, Bhuju S, Krause H J, Hartmann M, Miethe P, Singh M, Keusgen M (2007). Magnetic biosensor for the detection of Yersinia pestis. Journal of Microbiological Methods, 68(2): 218-224

Mobed A, Hasanzadeh M, Hassanpour S, Saadati A, Agazadeh M, Mokhtarzadeh A (2019a). An innovative nucleic acid based biosensor toward detection of Legionella pneumophila using DNA immobilization and hybridization: A novel genosensor. Microchemical Journal, 148: 708-716

Mobed A, Nami F, Hasanzadeh M, Hassanpour S, Saadati A, Mokhtarzadeh A (2019b). novel nucleic acid based bio-assay toward recognition of Haemophilus influenza using bioconjugation and DNA hybridization method. International Journal of Biological Macromolecules, 139: 1239-1251

Moradi M, Sattarahmady N, Rahi A, Hatam G R, Sorkhabadi S M R, Heli H (2016). A label-free, PCR-free and signal-on electrochemical DNA biosensor for Leishmania major based on gold nanoleaves. Talanta, 161: 48-53

Moreno-Bondi M C, Taitt C R, Shriver-Lake L C, Ligler F S (2006). Multiplexed measurement of serum antibodies using an array biosensor. Biosensors \& Bioelectronics, 21(10): 1880-1886

Muhammad-Tahir Z, Alocilja E C (2003). Fabrication of a disposable biosensor for Escherichia coli O157:H7 detection. IEEE Sensors Journal, 3(4): 345-351

Nasseri B, Soleimani N, Rabiee N, Kalbasi A, Karimi M, Hamblin M R (2018). Point-of-care microfluidic devices for pathogen detection. Biosensors \& Bioelectronics, 117: 112-128

Nguyen V T, Seo H B, Kim B C, Kim S K, Song C S, Gu M B (2016). Highly sensitive sandwich-type SPR based detection of whole $\mathrm{H} 5 \mathrm{Nx}$ viruses using a pair of aptamers. Biosensors \& Bioelectronics, 86: 293-300

Nidzworski D, Pranszke P, Grudniewska M, Król E, Gromadzka B (2014). Universal biosensor for detection of influenza virus. Biosensors \& Bioelectronics, 59: 239-242

Nugaeva N, Gfeller K Y, Backmann N, Duggelin M, Lang H P, Guntherodt H J, Hegner M (2007). An antibody-sensitized microfabricated cantilever for the growth detection of Aspergillus niger spores. Microscopy and Microanalysis, 13(1): 13-17

Pal S, Alocilja E C, Downes F P (2007). Nanowire labeled direct-charge transfer biosensor for detecting Bacillus species. Biosensors \&
Bioelectronics, 22(9-10): 2329-2336

Paolucci M, Landini M P, Sambri V (2010). Conventional and molecular techniques for the early diagnosis of bacteraemia. International Journal of Antimicrobial Agents, 36: S6-S16

Parab H J, Jung C, Lee J H, Park H G (2010). A gold nanorod-based optical DNA biosensor for the diagnosis of pathogens. Biosensors \& Bioelectronics, 26(2): 667-673

Park T J, Hyun M S, Lee H J, Lee S Y, Ko S (2009). A self-assembled fusion protein-based surface plasmon resonance biosensor for rapid diagnosis of severe acute respiratory syndrome. Talanta, 79(2): 295301

Peláez E C, Estevez M C, Mongui A, Menéndez M C, Toro C, HerreraSandoval O L, Robledo J, García M J, Portillo P D, Lechuga L M (2020). Detection and quantification of $\mathrm{HspX}$ antigen in sputum samples using plasmonic biosensing: toward a real point-of-care (POC) for tuberculosis diagnosis. ACS Infectious Diseases, 6(5): $1110-1120$

Phunpae P, Chanwong S, Tayapiwatana C, Apiratmateekul N, Makeudom A, Kasinrerk W (2014). Rapid Diagnosis of tuberculosis by identification of Antigen 85 in mycobacterial culture system. Diagnostic Microbiology and Infectious Disease, 78(3): 242-248

Pineda M F, Chan L L Y, Kuhlenschmidt T, Choi C J, Kuhlenschmidt M, Cunningham B T (2009). Rapid specific and label-free detection of porcine Rotavirus using photonic crystal biosensors. IEEE Sensors Journal, 9(4): 470-477

Qiu G, Gai Z, Tao Y, Schmitt J, Kullak-Ublick G A, Wang J (2020). Dual-functional plasmonic photothermal biosensors for highly accurate severe acute respiratory syndrome coronavirus 2 detection. ACS Nano, 14(5): 5268-5277

Rai V, Nyine Y T, Hapuarachchi H C, Yap H M, Ng L C, Toh C S (2012). Electrochemically amplified molecular beacon biosensor for ultrasensitive DNA sequence-specific detection of Legionella sp. Biosensors \& Bioelectronics, 32(1): 133-140

Razzini K, Castrica M, Menchetti L, Maggi L, Negroni L, Orfeo N V, Pizzoccheri A, Stocco M, Muttini S, Balzaretti C M (2020). SARSCoV-2 RNA detection in the air and on surfaces in the COVID-19 ward of a hospital in Milan, Italy. Science of the Total Environment, 742: 140540

Rufino de Sousa N, Sandstrrom N, Shen L, Håkansson K, Vezozzo R, Udekwu K I, Croda J, Rothfuchs A G (2020). A fieldable electrostatic air sampler enabling tuberculosis detection in bioaerosols. Tuberculosis (Edinburgh, Scotland), 120: 101896

Schlaberg R, Chiu C Y, Miller S, Procop G W, Weinstock G (2017). Validation of metagenomic next-generation sequencing tests for universal pathogen detection. Archives of Pathology \& Laboratory Medicine, 141(6): 776-786

Sedighi-Khavidak S, Mazloum-Ardakani M, Khorasgani M R, Emtiazi $\mathrm{G}$, Hosseinzadeh L (2017). Detection of afD gene in contaminated pistachio with Aspergillus flavus by DNA based electrochemical biosensor. International Journal of Food Properties, 20(Sup1): S119S130

Seibel A, Heinz W, Greim C A, Weber S (2020). Lung ultrasound in COVID-19. Anaesthesist (Published online),

Seo G, Lee G, Kim M J, Baek S H, Choi M, Ku K B, Lee C S, Jun S M, Park D, Kim S J, Lee J O, Kim B T, Park E C, Kim S (2020). Rapid detection of COVID-19 causative virus (SARS-CoV-2) in human 
nasopharyngeal swab specimens using field-effect transistor-based Biosensor. ACS Nano, 14(4): 5135-5142

Setti L, Passarini F, de Gennaro G, Barbieri P, Perrone M G, Borelli M, Palmisani J, Di Gilio A, Torboli V, Fontana F, Clemente L, Pallavicini A, Ruscio M, Piscitelli P, Miani A (2020). SARS-Cov2RNA found on particulate matter of Bergamo in Northern Italy: First evidence. Environmental Research, 188: 109754

Sheikhzadeh E, Chamsaz M, Turner A P F, Jager E W H, Beni V (2016). Label-free impedimetric biosensor for Salmonella typhimurium detection based on poly [pyrrole-co-3-carboxyl-pyrrole] copolymer supported aptamer. Biosensors \& Bioelectronics, 80: 194-200

Shen F, Tan M, Wang Z, Yao M, Xu Z, Wu Y, Wang J, Guo X, Zhu T (2011). Integrating silicon nanowire field effect transistor, microfluidics and air sampling techniques for real-time monitoring biological aerosols. Environmental Science \& Technology, 45(17): 7473-7480

Shen F, Wang J, Xu Z, Wu Y, Chen Q, Li X, Jie X, Li L, Yao M, Guo X, Zhu $T$ (2012). Rapid flu diagnosis using silicon nanowire sensor. Nano Letters, 12(7): 3722-3730

Shen Z, Wang J, Qiu Z, Jin M, Wang X, Chen Z, Li J, Cao F (2009). Detection of Escherichia coli O157:H7 with piezoelectric immunosensor based on enhancement with immuno-nanoparticles. Acta Microbiologica Sinica, 49(6): 820-825

Silva Junior A G, Oliveira M D L, Oliveira I S, Lima-Neto R G, Sá S R, Franco O L, Andrade C A S (2018). A simple nanostructured impedimetric biosensor based on clavanin a peptide for bacterial detection. Sensors and Actuators. B, Chemical, 255: 3267-3274

Soler M, Belushkin A, Cavallini A, Kebbi-Beghdadi C, Greub G, Altug H (2017). Multiplexed nanoplasmonic biosensor for one-step simultaneous detection of Chlamydia trachomatis and Neisseria gonorrhoeae in urine. Biosensors \& Bioelectronics, 94: 560-567

Song L, Wang C, Wang Y (2020). Optimized determination of airborne tetracycline resistance genes in laboratory atmosphere. Frontiers of Environmental Science \& Engineering, 14(6): 95

Su L C, Chang C M, Tseng Y L, Chang Y F, Li Y C, Chang Y S, Chou C (2012). Rapid and highly sensitive method for influenza A (H1N1) virus detection. Analytical Chemistry, 84(9): 3914-3920

Tian J, Wang D, Zheng Y, Jing T (2017). A high sensitive electrochemical avian influenza virus $\mathrm{H} 7$ biosensor based on CNTs/ MoSx aerogel. International Journal of Electrochemical Science, 12 (4): 2658-2668

Vásquez G, Rey A, Rivera C, Iregui C, Orozco J (2017). Amperometric biosensor based on a single antibody of dual function for rapid detection of Streptococcus agalactiae. Biosensors \& Bioelectronics, 87: 453-458

Wang L, Huo X, Zheng L, Cai G, Wang Y, Liu N, Wang M, Lin J (2020a). An ultrasensitive biosensor for colorimetric detection of Salmonella in large-volume sample using magnetic grid separation and platinum loaded zeolitic imidazolate Framework-8 nanocatalysts. Biosensors \& Bioelectronics, 150: 111862

Wang L, Huo X T, Qi W, Xia Z, Li Y, Lin J (2020b). Rapid and sensitive detection of Salmonella Typhimurium using nickel nanowire bridge for electrochemical impedance amplification. Talanta, 211: 120715

Wang Y, Wang C, Song L (2019a). Distribution of antibiotic resistance genes and bacteria from six atmospheric environments: Exposure risk to human. Science of the Total Environment, 694: 133750

Wang Y, Wang Y, Jiao W, Li J, Quan S, Sun L, Wang Y, Qi X, Wang X, Shen A (2019b). Development of loop-mediated isothermal amplification coupled with nanoparticle-based lateral flow biosensor assay for Mycoplasma pneumoniae detection. AMB Express, 9(1): 196

Wang Y, Wang Y, Quan S, Jiao W, Li J, Sun L, Wang Y, Qi X, Wang X, Shen A (2019c). Establishment and application of a multiple cross displacement amplification coupled with nanoparticle-based lateral flow biosensor assay for detection of Mycoplasma pneumoniae. Frontiers in Cellular and Infection Microbiology, 9: 325

Wasik D, Mulchandani A, Yates M V (2017). A heparin-functionalized carbon nanotube-based affinity biosensor for dengue virus. Biosensors \& Bioelectronics, 91: 811-816

Wei H, Guo Z, Zhu Z, Tan Y, Du Z, Yang R (2007). Sensitive detection of antibody against antigen F1 of Yersinia pestis by an antigen sandwich method using a portable fiber optic biosensor. Sensors and Actuators. B, Chemical, 127(2): 525-530

Wei X, Zheng L, Luo F, Lin Z, Guo L, Qiu B, Chen G (2013). Fluorescence biosensor for the H5N1 antibody based on a metalorganic framework platform. Journal of Materials Chemistry. B, Materials for Biology and Medicine, 1(13): 1812-1817

Weile J, Knabbe C (2009). Current applications and future trends of molecular diagnostics in clinical bacteriology. Analytical and Bioanalytical Chemistry, 394(3): 731-742

Wen N, Liu H, Fu Y, Wang C (2017). Optimization and influence mechanism of sampling and analysis of airborne endotoxin based on limulus amebocyte lysate assay. Aerosol and Air Quality Research, 17(4): 1000-1010

Wu K, Ma C, Zhao H, Chen M, Deng Z (2019). Sensitive aptamer-based fluorescene assay for ochratoxin A based on RNase $\mathrm{H}$ signal amplification. Food Chemistry, 277: 273-278

Wu Z, Zhou C, Chen J, Xiong C, Chen Z, Pang D, Zhang Z (2015). Bifunctional magnetic nanobeads for sensitive detection of avian influenza A (H7N9) virus based on immunomagnetic separation and enzyme-induced metallization. Biosensors \& Bioelectronics, 68: 586-592

Xiao T, Huang J, Wang D, Meng T, Yang X (2020). Au and Au-based nanomaterials: synthesis and recent progress in electrochemical sensor applications. Talanta, 206: 120210

Xie X, Tan F, Xu A, Deng K, Zeng Y, Huang H (2019a). UV-induced peroxidase-like activity of gold nanoclusters for differentiating pathogenic bacteria and detection of enterotoxin with colorimetric readout. Sensors and Actuators. B, Chemical, 279: 289-297

Xie X, Zhang Z, Ge X, Zhao X, Hao L, Cheng Z, Zhou W, Du Y, Wang L, Tian F, Xu X (2019b). Particle self-aligning, focusing, and electric impedance microcytometer device for label-free single cell morphology discrimination and Yeast budding analysis. ACS analytical chemistry, 91: 13398-13406

Xing Y, Zhu Q, Zhou X, Qi P (2020). A dual-functional smartphonebased sensor for colorimetric and chemiluminescent detection: A case study for fluoride concentration mapping. Sensors and Actuators. B, Chemical, 319: 128254

Xu S, Sharma H, Mutharasan R (2010). Sensitive and selective detection of Mycoplasma in cell culture samples using cantilever sensors. Biotechnology and Bioengineering, 105(6): 1069-1077

Xu Y, Xie X, Duan Y, Wang L, Cheng Z, Cheng J (2016). A review of 
impedance measurements of whole cells. Biosensors \& Bioelectronics, 77: 824-836

Yadav S K, Agrawal B, Chandra P, Goyal R N (2014). In vitro chloramphenicol detection in a Haemophilus influenza model using an aptamer-polymer based electrochemical biosensor. Biosensors \& Bioelectronics, 55: 337-342

Yan Z, Zhou L, Zhao Y, Wang J, Huang L, Hu K, Liu H, Wang H, Guo Z, Song Y, Huang H, Yang R (2006). Rapid quantitative detection of Yersinia pestis by lateral-flow immunoassay and up-converting phosphor technology-based biosensor. Sensors and Actuators. B, Chemical, 119(2): 656-663

Yang Y, Gao W (2019). Wearable and flexible electronics for continuous molecular monitoring. Chemical Society Reviews, 48(6): 1465-1491

Ye W W, Tsang M K, Liu X, Yang M, Hao J (2014). Upconversion luminescence resonance energy transfer (LRET)-based biosensor for rapid and ultrasensitive detection of avian influenza virus $\mathrm{H} 7$ subtype. Small, 10(12): 2390-2397

Yeh C H, Chang Y H, Chang T C, Lin H P, Lin Y C (2010). Electromicrochip DNA-biosensor for bacteria detection. Analyst (London), 135(10): 2717-2722

Yoo M S, Shin M, Kim Y, Jang M, Choi Y E, Park S J, Choi J, Lee J, Park C (2017). Development of electrochemical biosensor for detection of pathogenic microorganism in Asian dust events. Chemosphere, 175: 269-274

Yu P, Zhu J, Zhang Z, Han Y (2020). A familial cluster of infection associated with the 2019 novel coronavirus indicating possible person-to-person transmission during the incubation period. Journal of Infectious Diseases, 221(11): 1757-1761

Yu X, Chen F, Wang R, Li Y (2018). Whole-bacterium SELEX of DNA aptamers for rapid detection of E.coli $\mathrm{O} 157: \mathrm{H} 7$ using a QCM sensor. Journal of Biotechnology, 266: 39-49

Yu Y, Chen Z, Jian W, Sun D, Zhang B, Li X, Yao M (2015). Ultrasensitive electrochemical detection of avian influenza A (H7N9) virus DNA based on isothermal exponential amplification coupled with hybridization chain reaction of DNAzyme nanowires. Biosensors \& Bioelectronics, 64: 566-571

Yuan R, Ding S, Yan Y, Zhang Y, Zhang Y, Cheng W (2016). A facile and pragmatic electrochemical biosensing strategy for ultrasensitive detection of DNA in real sample based on defective $\mathrm{T}$ junction induced transcription amplification. Biosensors \& Bioelectronics, 77: $19-25$

Zeinoddini M, Azizi A, Bayat S, Tavasoli Z (2018). Localized surface plasmon resonance (LSPR) detection of diphtheria toxoid using gold nanoparticle-monoclonal antibody conjugates. Plasmonics, 13(2): $583-590$

Zhang G, Zhang L, Huang M J, Luo Z H H, Tay G K I, Lim E J A, Kang T G, Chen Y (2010). Silicon nanowire biosensor for highly sensitive and rapid detection of Dengue virus. Sensors and Actuators. B, Chemical, 146(1): 138-144

Zhang J, Huang J, He F (2019a). The construction of Mycobacterium tuberculosis 16S rDNA MSPQC sensor based on Exonuclease IIIassisted cyclic signal amplification. Biosensors \& Bioelectronics, 138: 111322

Zhang X, Feng Y, Duan S, Su L, Zhang J, He F (2019b). Mycobacterium tuberculosis strain $\mathrm{H} 37 \mathrm{Rv}$ electrochemical sensor mediated by aptamer and AuNPs-DNA. ACS Sensors, 4(4): 849-855

Zhang X, Feng Y, Yao Q, He F (2017). Selection of a new Mycobacterium tuberculosis $\mathrm{H} 37 \mathrm{Rv}$ aptamer and its application in the construction of a SWCNT/aptamer/Au-IDE MSPQC H37Rv sensor. Biosensors \& Bioelectronics, 98: 261-266

Zhang Y, Lai B S, Juhas M (2019c). Recent advances in aptamer discovery and applications. Molecules (Basel, Switzerland), 24(5): 941

Zheng L, Cai G, Wang S, Liao M, Li Y, Lin J (2019). A microfluidic colorimetric biosensor for rapid detection of Escherichia coli O157: H7 using gold nanoparticle aggregation and smart phone imaging. Biosensors \& Bioelectronics, 124-125: 143-149

Zheng Y, Chen H, Yao M, Li X (2018). Bacterial pathogens were detected from human exhaled breath using a novel protocol. Journal of Aerosol Science, 117: 224-234

Ziółkowski R, Jarczewska M, Drozd M, Zasada A A, Malinowska E (2019). Studies on the development of electrochemical immunosensor for detection of diphtheria toxoid. Journal of the Electrochemical Society, 166(6): B472-B481

Zuser K, Ettenauer J, Kellner K, Posnicek T, Mazza G, Brandl M (2019). A sensitive voltammetric biosensor for Escherichia coli detection using an electroactive substrate for beta-D-glucuronidase. IEEE Sensors Journal, 19(18): 7789-7802 